\title{
The Effects of Intrinsic and Environmental Factors on the Oxygen Consumption of the Blue Crab, Callinectes sapidus Rathbun
}

Chae E. Laird

College of William and Mary - Virginia Institute of Marine Science

Follow this and additional works at: https://scholarworks.wm.edu/etd

Part of the Marine Biology Commons, Oceanography Commons, and the Physiology Commons

\section{Recommended Citation}

Laird, Chae E., "The Effects of Intrinsic and Environmental Factors on the Oxygen Consumption of the Blue Crab, Callinectes sapidus Rathbun" (1973). Dissertations, Theses, and Masters Projects. Paper 1539617454.

https://dx.doi.org/doi:10.25773/v5-vrdn-8q74

This Thesis is brought to you for free and open access by the Theses, Dissertations, \& Master Projects at W\&M ScholarWorks. It has been accepted for inclusion in Dissertations, Theses, and Masters Projects by an authorized administrator of W\&M ScholarWorks. For more information, please contact scholarworks@wm.edu. 


\title{
THE EFFECTS OF INTRINSIC AND ENVIRONMENTAL FACTORS ON THE OXYGEN CONSUMPTION OF THE BLUE CRAB, CALLINECTES SAPIDUS RATHBUN
}

\begin{abstract}
A Thesis
Presented to The Faculty of the School of Marine Science The College of William and Mary in Virginia
\end{abstract}

In Partial Fulfillment Of the Requirements for the Degree of. Master of Arts

by

Chae E. Laird

1973 
ProQuest Number: 10625298

All rights reserved

INFORMATION TO ALL USERS

The quality of this reproduction is dependent upon the quality of the copy submitted.

In the unlikely event that the author did not send a complete manuscript and there are missing pages, these will be noted. Also, if material had to be removed, a note will indicate the deletion.

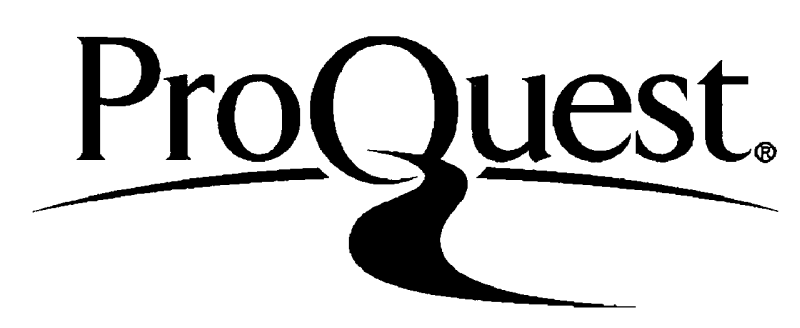

ProQuest 10625298

Published by ProQuest LLC (2017). Copyright of the Dissertation is held by the Author.

All rights reserved.

This work is protected against unauthorized copying under Title 17, United States Code Microform Edition (c) ProQuest LLC.

ProQuest LLC.

789 East Eisenhower Parkway

P.O. Box 1346

Ann Arbor, Ml $48106-1346$ 
This thesis is submitted in partial fulfillment of the requirements for the degree of

\section{Master of Arts}

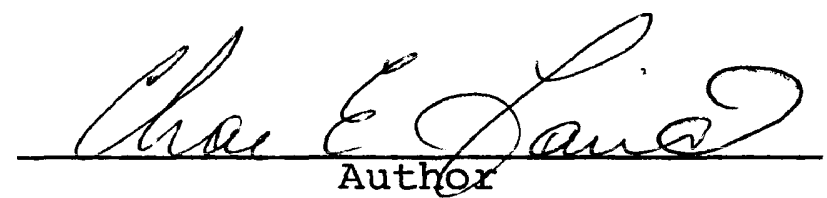

Approved, August 1973
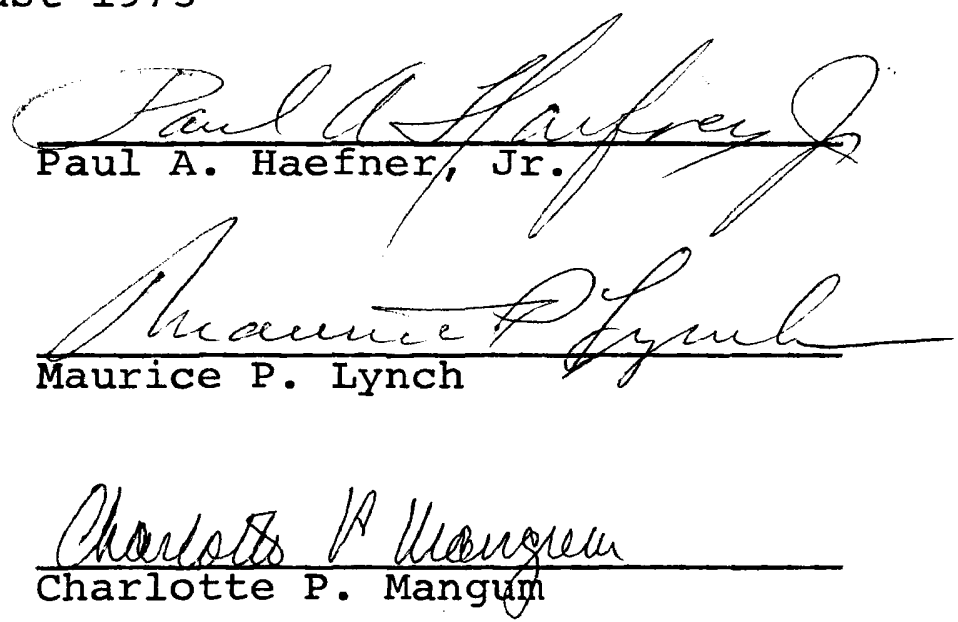

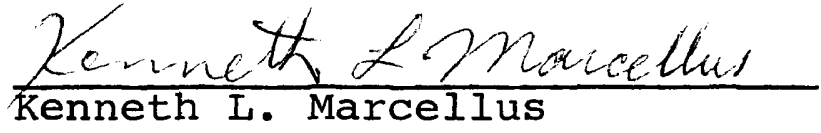

$\frac{\text { David Dow }}{\text { David D. Dow }}$


TABLE OF CONTENTS

Page

ACKNOWLEDGMENTS • • • • • • • • • • • • • • • • • • • iv

LIST OF TABLES. • • • • • • • • • • • • • • • • • • . V v

LIST OF FIGURES • • • • • • • • • • • • • • • • • • . vi vi

ABSTRACT. . . . . . . . . . . . . . . . . . . . vii

INTRODUCTION. • • • • • • • • • • • • • • • • • • 2

METHODS AND MATERIALS • . • . • • • . • • • • . . . 4

Experimental Design. • . • . • . • • • . . . 4

Experimental Animals • • • • • • • • • • • • 5

Equipment. • • • • • • • • • • • • • • • • 7

Respirometric Technique. • . • . • . . • . 11

Calculations . . . . . . . . . . . . . . 14

RESULTS • • • • • • • • • • • • • • • • • • • • • • 15

DISCUSSION. • • • • • • • • • • • • • • • • • • 30

Variability. . • . . . . . . . . . . . 30

Weight • • • • • • • • • • • • • • • 33

Sex. • • . . • . . . . . . . . . . . . 34

Salinity • . • • • . . • . . • . . . 35

Temperature. • . . . . . . . . . . . . 40

Oxygen . . . . . . . . . . . . . . . . . 44

SUMMARY • • • • • • • • • • • • • • • • • • • • • •

APPENDICES • • • • • • • • • • • • • • • • • • •

LITERATURE CITED. • • • • • • • • • • • • • • • • 52 


\section{ACKNOWLEDGMENTS}

The author expresses appreciation to Dr. Paul A. Haefner, Jr. for his able guidance and unfaltering support during the course of this study. Additional thanks are extended to Drs. Maurice P. Lynch, Charlotte P. Mangum, Kenneth I. Marcellus, and David D. Dow for their critical review of the manuscript. Special consideration is extended to Mrs. Joanne Lewis, without whose assistance this study could not have been started, to Mrs. Jane Davis and Mrs. Kay stubblefield, who drafted the figures, and to the author's wife, Beverly, who provided continuous moral support and typed the manuscript.

This research was made possible by a traineeship endowed by the National Science Foundation from September 1970 to March 1973 and was sponsored in part by the National Oceanic and Atmospheric Administration, Office of sea Grant, Department of Commerce, under P. L. 89-688 (Grant Nos. 1-36032, N.G. 5-72 and 04-3-158-49). 


\section{LIST OF TABLES}

Table

Page

1. Four factor analysis of variance for

the effects of acclimation temperature, acclimation salinity, experimental

temperature, and experimental salinity

on the oxygen consumption of Callinectes

sapidus • • • • • • • • • • • • • • • • 21

2. Student-Newman-Keuls multiple comparison

test for the cell means from the

temperature-salinity experiment . . . . . . . 22

3. Student-Newman-Keuls multiple comparison

test for the cell means from the

temperature-salinity experiment. Experi-

mental salinities are pooled. . . . . . . . 25

4. Temperature coefficients $\left(Q_{10} ' s\right)$ for the oxygen consumption-experimental temperature curves from the temperaturesalinity experiment. Experimental salinities are pooled

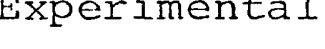




\section{LIST OF FIGURES}

Figure

Page

1. Complete respirometer assembly used to determine the oxygen consumption of Callinectes sapidus . . . . . . . . . . . . . 8

2. Animal chambers from the respirometer showing the geometry of their construction. . . 9

3. Detail of the construction of the oxygen probe fittings (bottom view on left, top view on right) used in the animal chambers. A probe has been inserted into the stopper on the left...................... . 10

4. Log-log plot of the regression of cxygen consumption on wet weight for male Callinectes sapidus . . . . . . . . . . . . 16

5. Log-log plot of the regression of oxygen consumption on wet weight for female Callinectes sapidus . . . . . . . . . . . . .

6. Log-log plot of the regression of oxygen consumption on wet weight for the pooled data from male and female callinectes sapidus

7. Four factor linear plot showing the effects of acclimation temperature, acclimation salinity, experimental temperature, and experimental salinity on the oxygen consumption of Callinectes sapidus . . . . . • • 20

8. Semi-log plot showing the effects of acclimation temperature, acclimation salinity, and experimental temperature on the oxygen consumption of Callinectes sapidus. Experimental salinities are pooled. . . . . . . . . . 


\section{ABSTRACT}

An analysis of covariance design was used to determine the effects of sex and weight, while a four factor design was used to determine the effects of salinity and temperature on the oxygen consumption of Callinectes sapidus Rathbun. The factors and their levels were as follows: acclimation temperature, $10^{\circ} \mathrm{C}, 24^{\circ} \mathrm{C}$; acclimation salinity, $10^{\circ} / 00$, $20 \% \% 00,30 \%$ oo; experimental temperature, $10^{\circ} \mathrm{C}, 17.5^{\circ} \mathrm{C}$, $25^{\circ} \mathrm{C}$; experimental salinity, $10^{\circ} / 00,20 \%, 30 \%$. A closed system respirometer was used, and oxygen levels were measured polarographically.

Under uniform conditions great variability between crabs was encountered in the oxygen consumption rates. Weight specific oxygen consumption was found to decrease with increasing wet weight from 20 to 200 grams. Sex has no effect on oxygen consumption over this same weight range. Oxygen consumption is little affected by experimental salinities from $10 \%$ to $30 \% / 00$. Acclimation to $10 \%$ and $30^{\circ} / 00$ has no effect on the oxygen consumption of $24^{\circ} \mathrm{C}$ acclimated crabs, but for crabs acclimated to $10^{\circ} \mathrm{C}$, simultaneous acclimation to $100 / 00$ produces higher oxygen consumption rates than acclimation to $30 \% / 00$. While oxygen consumption increases significantly with experimental

temperature from $10^{\circ} \mathrm{C}$ to $25^{\circ} \mathrm{C}$, consistent increases are exhibited only by $10^{\circ} \mathrm{C}$ acclimated crabs. The oxygen consumption of $240^{\circ} \mathrm{C}$ acclimated crabs increases greatly from $10^{\circ} \mathrm{C}$ to $17.5^{\circ} \mathrm{C}$ but is relatively independent of temperature from $17.5^{\circ} \mathrm{C}$ to $25^{\circ} \mathrm{C}$. The expected higher rate function of $10^{\circ} \mathrm{C}$ acclimated crabs over $24^{\circ} \mathrm{C}$ acclimated crabs does not occur for the intermediate experimental temperature and is attributed to incomplete acclimation. It was found during the study that $\underline{C}$. sapidus regulates its oxygen uptake relatively independent of the dissolved oxygen supply down to an average critical level of $2.5 \mathrm{mg} / 1$. This level is unaffected by sex or weight. 
THE EFFECTS OF INTRINSIC AND ENVIRONMENTAL FACTORS ON THE OXYGEN CONSUMPTION OF THE BLUE CRAB, CALLINECTES SAPIDUS RATHBUN 


\section{INTRODUCTICN}

Historically, research on the blue crab, Callinectes sapidus Rathbun, has been stimulated by its abundance and economic importance. Increasing interest in the effects of environmental pollution on this valuable resource, as well as interest in mariculture of the crab, has prompted a shift in research emphasis to physiological aspects (Tagatz, 1971).

The oxygen consumption of the blue crab has, however, been studied by both early and recent investigators. For this reason some information about the effects of intrinsic and environmental factors on the crab's oxygen consumption is available. It has been suggested or demonstrated that the blue crab is an oxyconformer (Amberson, et al., 1924), sex has no effect on the oxygen consumption of selected excised tissues (Vernberg, 1956), the crab's oxygen consumption increases with temperature (Scholander et al., 1953; Leffler, 1972), and its metabolism is higher in decreased salinity (King, 1965). In addition, the oxygen consumption of the blue crab has been related to habitat (Ayers, 1935) and has been used as an indicator of both sodium fluxes across gill membranes (Mantel, 1967) and 
thermal acclimation (Robert, 1971). The effect of weight on the crab's oxygen consumption has not been investigated, however, and only Robert (1971) and, possibly, Ayers (1938) have determined the oxygen consumption of intact, adult crabs.

The present study is designed to supplement existing studies on the oxygen consumption of the blue crab by providing information on the effects of $s \in x$ and weight on the oxygen consumption of intact crabs and the effects of temperature and salinity on the oxygen consumption of intact, male adult crabs. 


\section{METHODS AND MATERIALS}

\section{Experimental Design}

An experimental design for the analysis of covariance was used to determine the effects of sex and weight on the oxygen consumption (standard metabolism) of Callinectes sapidus. The intent was to determine the oxygen consumption for crabs from a wide range of weights and to compare the effect of weight for both sexes. The 20-200 gram weight range was subdivided into nine 20-gram ranges, and a quota of six crabs for each sex was assigned to each range. Throughout the experiment, crabs were selected randomly until all the quotas were filled.

A $2 \times 2 \times 3 \times 3$ factorial design with five replicates was used to determine the effects of temperature and salinity on the oxygen consumption of adult male crabs. The factors were fixed, and their levels were as follows:

Factor \#1 (acclimation temperature): $10^{\circ} \mathrm{C}, 24^{\circ} \mathrm{C}$ Factor \#2 (acclimation salinity): $10 \%$ Factor \#3 (experimental temperature): $10^{\circ} \mathrm{C}, 17.5^{\circ} \mathrm{C}, 25^{\circ} \mathrm{C}$ Factor \#4 (experimental salinity): $10^{\circ} / 00,20^{\circ} / 00,30^{\circ} / 00$ 
Experimental Animals

The crabs for the sex-weight experiment were captured in a boat basin on the western side of Gloucester Point, Virginia, in May and June, 1972. The salinity ranged from $6.7^{\circ} / 00$ to $14.9^{\circ} / 00$, and the temperature ranged from $20.5^{\circ} \mathrm{C}$ to $25^{\circ} \mathrm{C}$. Six standard crab pots (Van Engel, 1962) were fished every morning during the experiment, and all intermolt crabs of the predetermined weight range were taken. Crabs with injuries or missing appendages were discarded. The crabs were held for at least one hour in the laboratory in a $1.22 \mathrm{~m} \times 1.22 \mathrm{~m} \times 0.25 \mathrm{~m}$ epoxy-coated wooden tank with continuously flowing, unfiltered York River water. The salinity ranged from $10.3 \%$ to $15.2 \%$ the temperature ranged from $20.5^{\circ} \mathrm{C}$ to $26^{\circ} \mathrm{C}$. Crabs were selected for each run of the experiment on the basis of how close they were to a fixed point in the tank. Crabs not used on any particular day were discarded.

Intermolt male crabs weighing from 150 to 220 grams for use in the temperature-salinity experiment were captured in pots in open water on the eastern side of Gloucester Point, Virginia, from July through september, 1972. The salinity ranged from $12^{\circ} / 00$ to $18^{\circ} / 00$, and the temperature ranged from $23.5^{\circ} \mathrm{C}$ to $28^{\circ} \mathrm{C}$. Injured crabs or crabs missing chelae were discarded, but a shortage of crabs at this time and location made it necessary to accept crabs with no more than one missing leg. All of the crabs were elastrated to 
prevent cannibalism (Haefner, 1971).

The crabs were held in recirculating York River water in two $1.22 \mathrm{~m} \times 2.44 \mathrm{~m} \times 0.31 \mathrm{~m}$ fiberglass tanks equipped with granular dolomite filters. The tanks were used in two shifts to accommodate each of the four possible combinations of acclimation conditions. Although 45 crabs were needed for each test, 60 were placed in each tank to allow for loss by death or escape.

One tank was equipped with a refrigeration unit for regulating water temperature within $\pm 1^{\circ} \mathrm{C}$. Crabs placed in this tank were exposed to $10^{\circ} \mathrm{C}$ at a decrement of about 1. $5^{\circ} \mathrm{C}$ per day. Crabs in the second tank were held at room temperature $\left(24+2^{\circ} \mathrm{C}\right)$. Salinities in both tanks were regulated to within $\pm 10 / 00$ by daily monitoring and adjustment with either well water or commercial saltwater aquarium salt.

The crabs were subjected acutely to the acclimation salinities because Tagatz (1971) reported that the body fluids of blue crabs require less than one day to adjust osmotically to a new salinity. The crabs were held at their acclimation conditions for 10-14 days before they were used and were fed daily with pieces of squid mantle. Crabs for which oxygen consumption was to be measured were not fed for at least 18 hours prior to the determination. 
Equipment

The oxygen consumption of $\underline{c}$. sapidus was determined in a closed system respirometer (Fig. 1), which was designed so that two simultaneous determinations could be made. Each of the two animal chambers had a volume of 3025 milliliters and was constructed of $6.35 \mathrm{~mm}$ Plexiglas (Fig. 2). The chambers consisted of $14.5 \mathrm{~cm}$ lengths of a $16.4 \mathrm{~cm}$ diameter Plexiglas cylinder closed off at the ends. The opening in each chamber was made tangential to the curvature of the chamber wall. This geometry aided in the removal of air bubbles prior to sealing the openings with \#15 rubber stoppers. Each chamber was equipped with a pneumatic magnetic stirrer. The chambers were submerged in a $100.5 \mathrm{~cm} \times 49.5 \mathrm{~cm} \times 25.5 \mathrm{~cm}$ water bath built from $6.35 \mathrm{~mm}$ Plexiglas, and the entire assembly was placed in a cold room, which allowed the determinations to be run in the dark with thermostatic temperature control.

The concentration of oxygen in the chambers was monitored continuously using Yellow Springs Instrument Company models $5420 \mathrm{~A}$ and 5418 oxygen probes, each connected to its own YSI model 54 oxygen meter. The meters were connected in turn to a single YSI model 8IA dual channel recorder (Fig. 1). Special fittings for the oxygen probes were made from plastic pipe fittings and were built into the rubber stoppers used to seal the animal chambers (Fig. 3). 
FIGURE 1. Complete respirometer assembly used to determine the oxygen consumption of Callinectes sapidus. 





FIGURE 2. Animal chambers from the respirometer showing the geometry of their construction. 


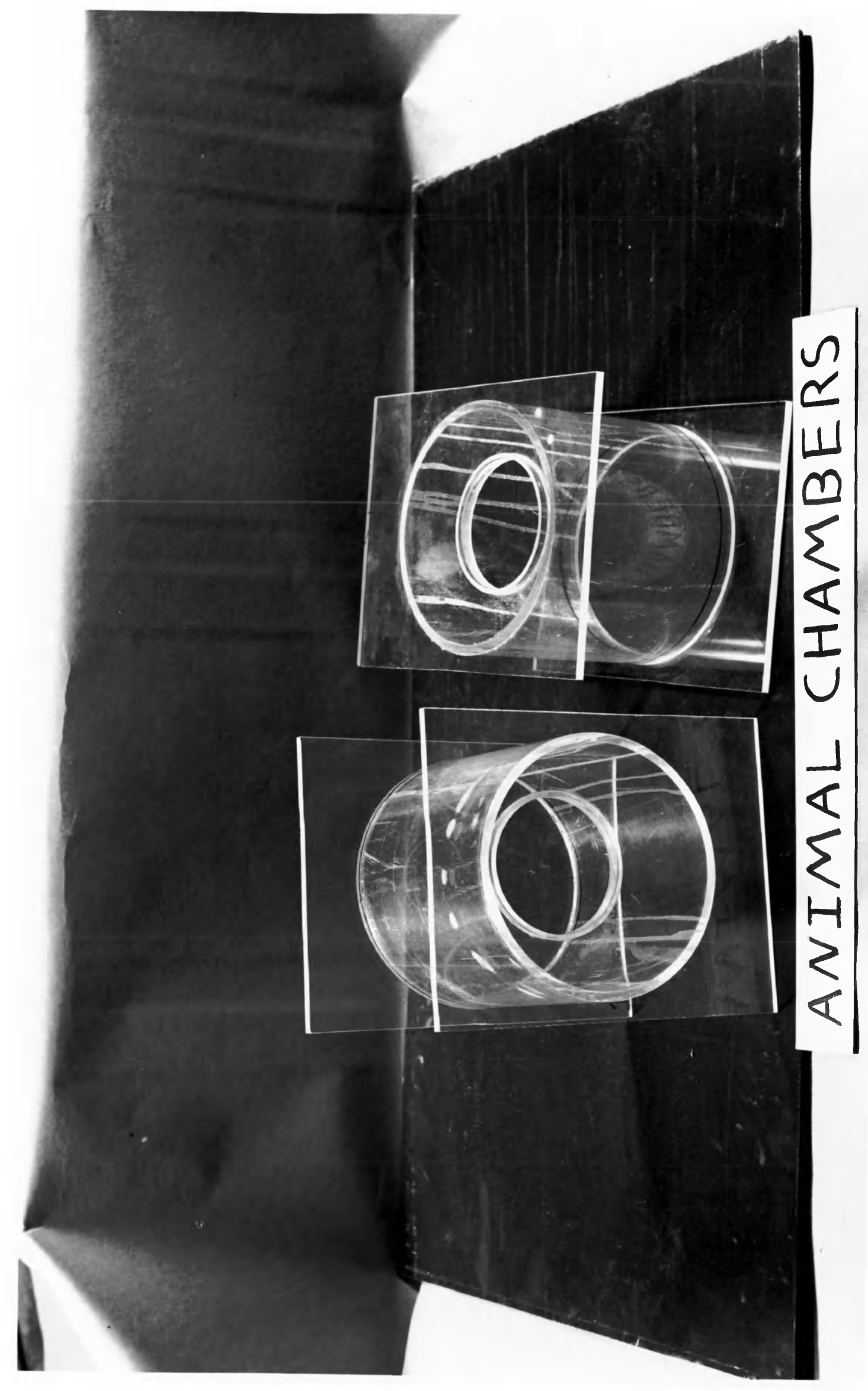


FIGURE 3. Detail of the construction of the oxygen probe fittings (bottom view on left, top view on right) used in the animal chambers. A probe has been inserted into the stopper on the left. 


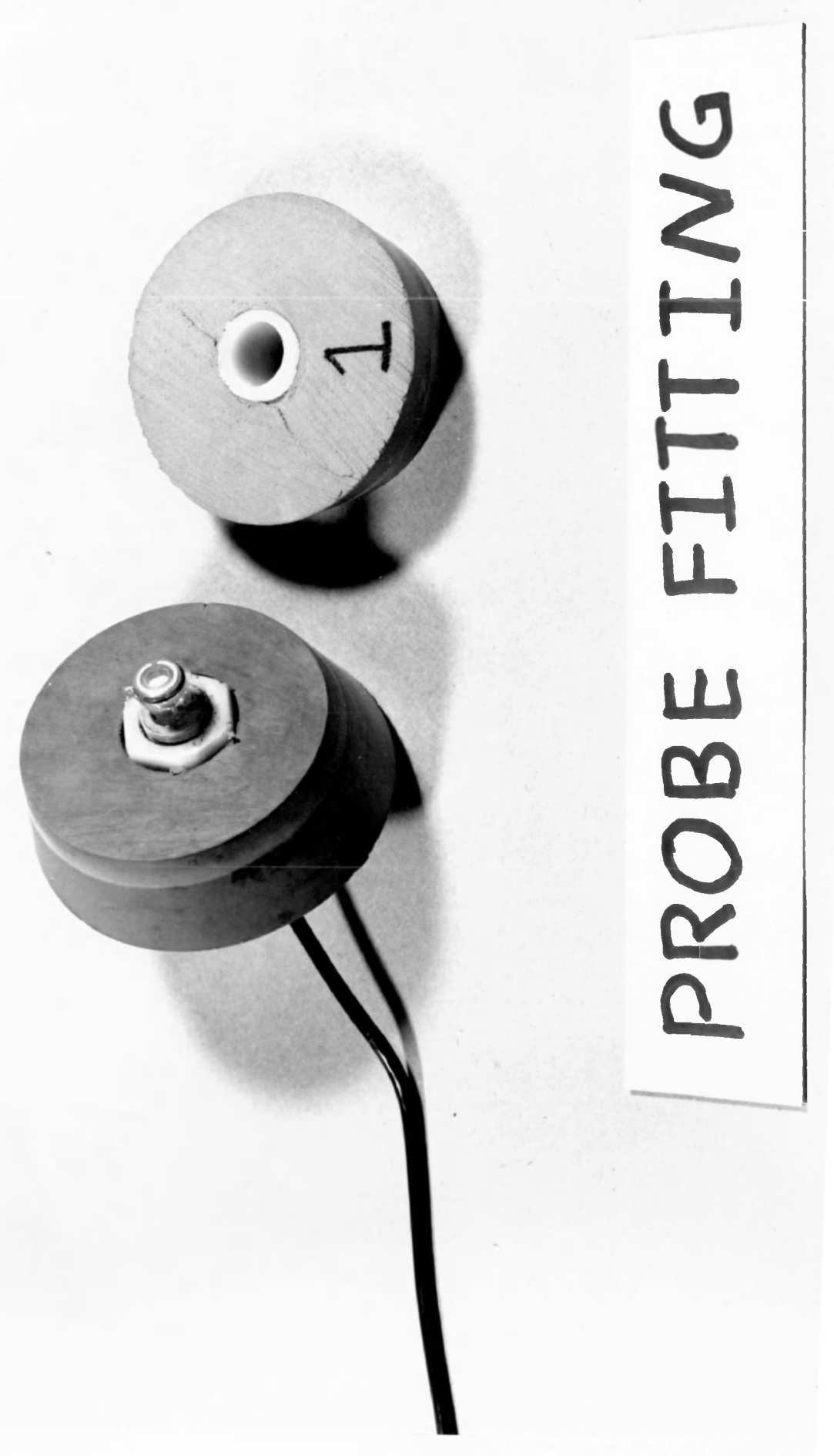


Salinities in the sex-weight experiment were determined through the use of USCGS hydrometers to a probable precision of $\pm 2 \%$. Salinities in the temperature-salinity experiment were determined with a Beckman RS-7A induction salinometer to the nearest $0.1 \%$. Temperatures for both experiments were determined with a stem thermometer to the nearest $0.1^{\circ} \mathrm{C}$.

Crabs were weighed to the nearest 0.1 gram on a triple beam balance. Volumes for the crabs from the sex-weight experiment were determined to the nearest $5 \mathrm{ml}$ by water displacement, either directly in a graduated cylinder or indirectly by collecting the overflow from a reservoir containing the crab. Volumes for the crabs from the temperature-salinity experiment were determined from a plot of volume against weight compiled for the crabs from the sex-weight experiment (see Appendix I).

Respirometric Technique

Although the basic respirometric technique was the same for both experiments, several differences did exist. For the sex-weight experiment, the water bath consisted of continuously flowing, filtered (10 microns), aerated York River water. The oxygen probes were calibrated by placing them in the aerated influent stream and referring to charts compiled for determining saturation values for dissolved oxygen in waters of differing temperatures and salinities 
(Green and Carritt, 1967). Calibration was performed for every run. Temperature was determined for every run, and salinity was monitored after every third or fourth run. After calibration, the chamber stirrers were turned on. A crab was placed into each chamber and was allowed 30 minutes to adjust to the apparatus. An airstone was put into each chamber during the adjustment period to prevent premature depletion of the dissolved oxygen supply. The crabs were not restrained in this experiment because injury to the smaller crabs could not have been avoided. Blanks were run periodically to test for background respiration by bacteria and other organisms. This was done by monitoring the oxygen level in a sealed animal chamber not containing a crab. No background respiration was detected. When the crabs had settled down in the chambers, the airstones were removed and the chamber stoppers were set in place. The oxygen probes were fitted into the stoppers and the room was darkened to prevent visual stimulation of the crabs. When the dissolved oxygen values reached $50 \%$ saturation as indicated on the recorder tape, or one hour had passed, the crabs were removed from the chambers, and the chamber water was discarded. The crabs were blotted dry and weighed. After volume determination, crabs were placed in preweighed trays in an oven at $87 \pm 5^{\circ} \mathrm{C}$ and dried to constant weight, a process which took five days. 
Preliminary information was desired about the effect of decreasing dissolved oxygen levels on the oxygen consumption of the blue crab. Therefore, several of the larger crabs from the sex-weight experiment were retained in the animal chambers and were allowed to deplete their dissolved oxygen supply to low levels.

For the temperature-salinity experiment, the water bath was closed. One of the nine possible experimental temperature-salinity combinations was chosen at random, and the water was prepared accordingly the day preceding the determination to allow time for further temperature and salinity adjustments. The salinity was adjusted to $\pm 1 \%$ by adding commercial saltwater aquarium salt or well water to York River water filtered to 1 micron. The temperature was adjusted to $\pm 1^{\circ} \mathrm{C}$ by changing the cold room temperature, or, if the desired temperature was above room temperature, by using commercial aquarium heaters. The water bath was aerated vigorously to achieve oxygen saturation and thorough mixing.

The oxygen probes were calibrated for each run inside the closed animal chambers with the stirrers running. This procedure also supplied blank runs. Then a crab from each acclimation temperature was put into an animal chamber. Since these crabs were large, it was feasible to bind their legs and chelae to their bodies with rubber bands. The procedure from this point was the same as for the sexweight experiment. 
Calculations

Oxygen consumption values were computed from the recording chart. Time in hours and milligrams/liter oxygen depletion were taken from the most linear part of the depletion curve within the 50-100\% saturation interval. If the crab did not deplete the dissolved oxygen to 50\% saturation, the most consistent rate of depletion within the first 30 minutes of the run was used. The oxygen consumption in microliters per gram wet weight per hour $\left(\mu \mathrm{IO}_{2} / \mathrm{g}\right.$ per $\left.\mathrm{hr}\right)$ was computed from the following formula:

$$
\begin{aligned}
\mu 10_{2} / \mathrm{g} \text { per } \mathrm{hr}= & \mathrm{mg} / \text { liter } \times \mathrm{V} \times 0.7 \mathrm{ml} / \mathrm{mg} \times 1 / \mathrm{g} \\
& \times 1 / \mathrm{hr} \times 1000 \mu 1 / \mathrm{ml}
\end{aligned}
$$

where

$$
\begin{aligned}
\mathrm{mg} / \text { liter }= & \text { oxygen depletion by the crab, } \\
\mathrm{V}= & \text { chamber volume - crab volume (liters), } \\
0.7 \mathrm{ml} / \mathrm{mg}= & \text { conversion factor (American Public } \\
& \text { Health Association, } 1971), \\
1 / \mathrm{g}= & \text { reciprocal of crab weight, } \\
1 / \mathrm{hr}= & \text { reciprocal of elapsed time, and } \\
1000 \mathrm{H} / \mathrm{ml}= & \text { conversion factor. }
\end{aligned}
$$

Statistical analysis for the sex-weight experiment was performed by IBM 1130 computer from programs compiled by the Department of Data Processing and statistical Services of the Virginia Institute of Marine Science. Statistical analysis for the temperature-salinity experiment was performed by IBM 360 computer from catalogued programs (Dixon, 1968). 


\section{RESULTS}

One very noticeable result is the high variability of the oxygen consumption of $\underline{C}$. sapidus for any given set of experimental conditions. This variability exists for values based on wet weight as well as on dry weight. Logarithmic transformation of the values in the temperaturesalinity experiment was necessary to prevent heterogeneity of variance. The variability of these transformed values was found not to differ between wet and dry weights (Appendix II). For this reason and to conform with other oxygen consumption studies on large crustaceans, only the wet weight values were used in the statistical analyses.

Generally, the weight specific oxygen consumption of the blue crab decreases with an increase in wet weight for both sexes over the range of weights studied (Figs. 4 and 5). The equations for the regression of oxygen consumption on weight are

$$
\log y=2.817-0.342 \log x ; r=-0.542
$$

for females and

$$
\log y=2.644-0.247 \log x ; r=-0.441
$$

for males. Although the slope of the regression line for the female crabs is slightly steeper than that for the 
FIGURE 4. Log-log plot of the regression of oxygen consumption on wet weight for male callinectes sapidus. 


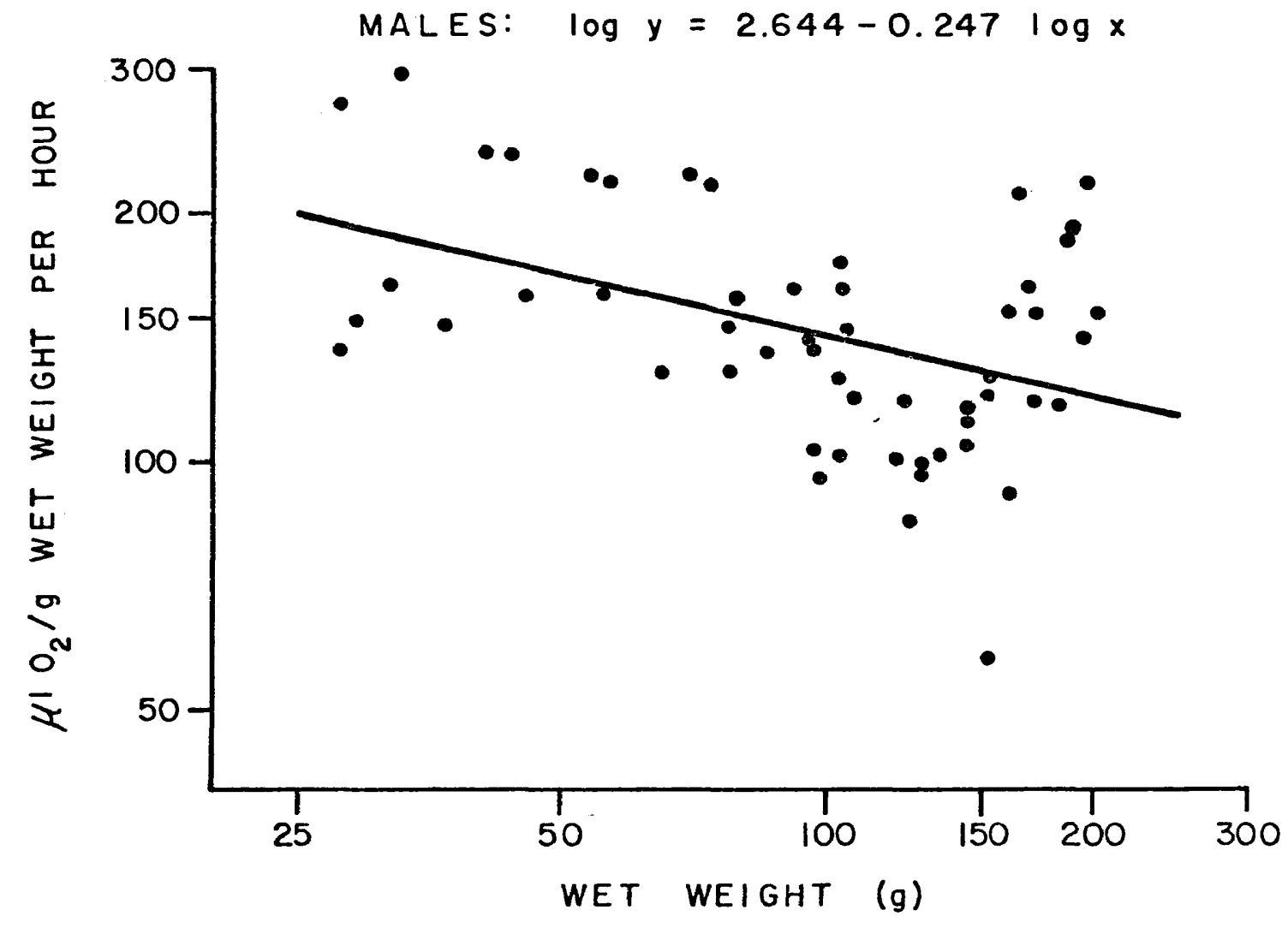




\section{FIGURE 5. Log-log plot of the regression of oxygen consumption on wet weight for female Callinectes sapidus.}




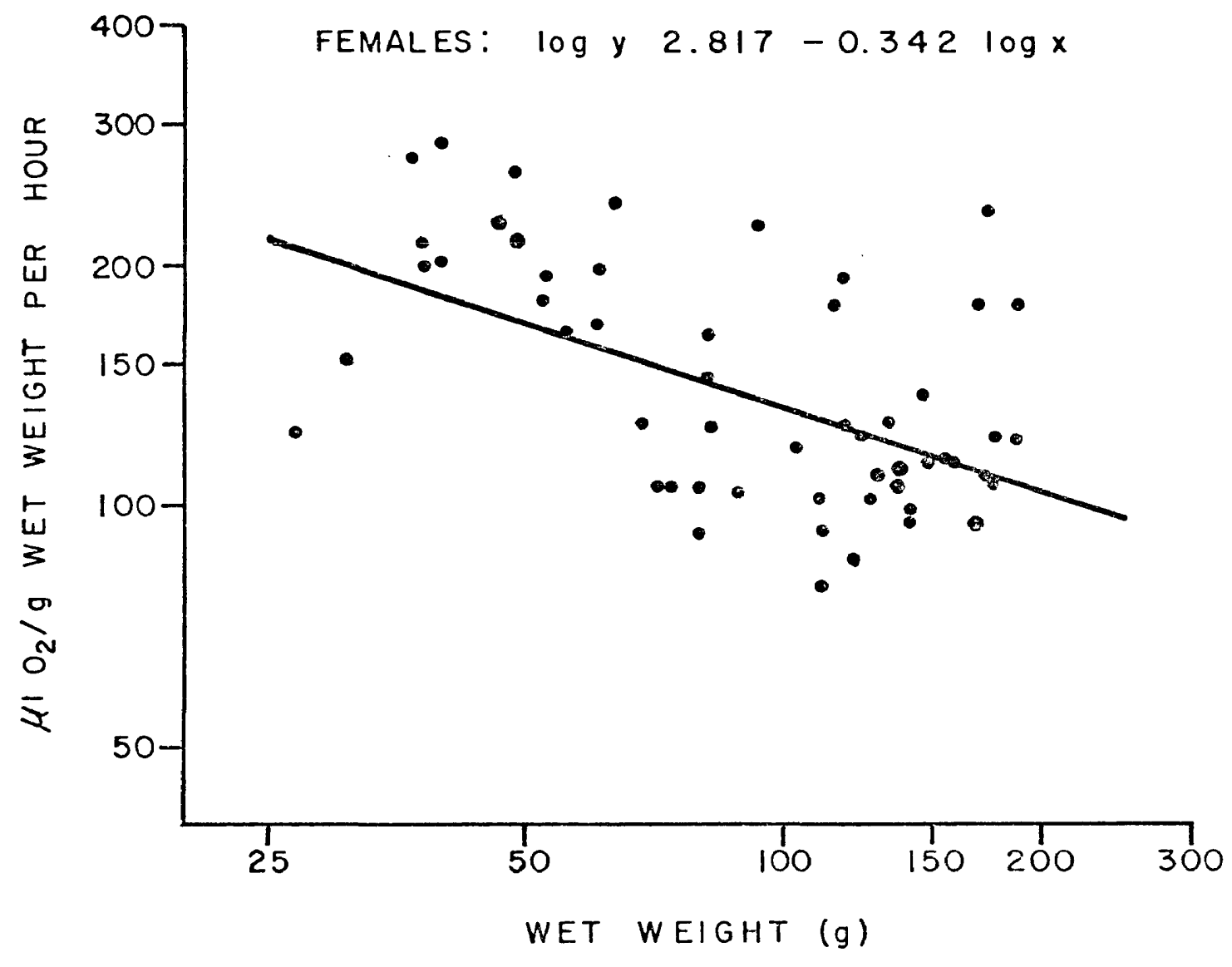


males, analysis of covariance indicated no significant difference in slope $(F=0.883, P>0.10)$ or adjusted mean $(\mathrm{F}=0.381, \mathrm{P}>0.10)$. Therefore, the data were pooled (Fig. 6). The resultant regression is defined by the equation

$$
\log y=2.721-0.289 \log \mathrm{x} ; \mathrm{r}=-0.489 .
$$

The slope was found to be significantly different from zero $(F=33.88, P<0.01)$. Although the correlation coefficients for the regressions are relatively low, they are all significantly different from zero $(\mathrm{P}<0.01)$. The effects of temperature and salinity on the oxygen consumption of $\underline{c}$. sapidus are shown in Figure 7 . Analysis of variance of the transformed data (Table 1) showed that significant effects exist at the $1 \%$ level for acclimation temperature, acclimation salinity, and experimental temperature, and at the 5\% level for experimental salinity. Significant interactions exist at the 1\% level for acclimation temperature and salinity and for acclimation and experimental temperature.

Although experimental salinity has a significant effect on oxygen consumption at the 5\% level, a comparison of means (Table 2) showed no change in oxygen consumption with experimental salinity for a given temperature and within a given acclimation condition. The only exception is that in crabs acclimated to $10^{\circ} \mathrm{C}$ and $10^{\circ} / 00$ and measured at $25^{\circ} \mathrm{C}$, the value for $20^{\circ} / 00$ is significantly 
FIGURE 6. Log-log plot of the regression of oxygen consumption on wet weight for the pooled data from male and female Callinectes sapidus. 


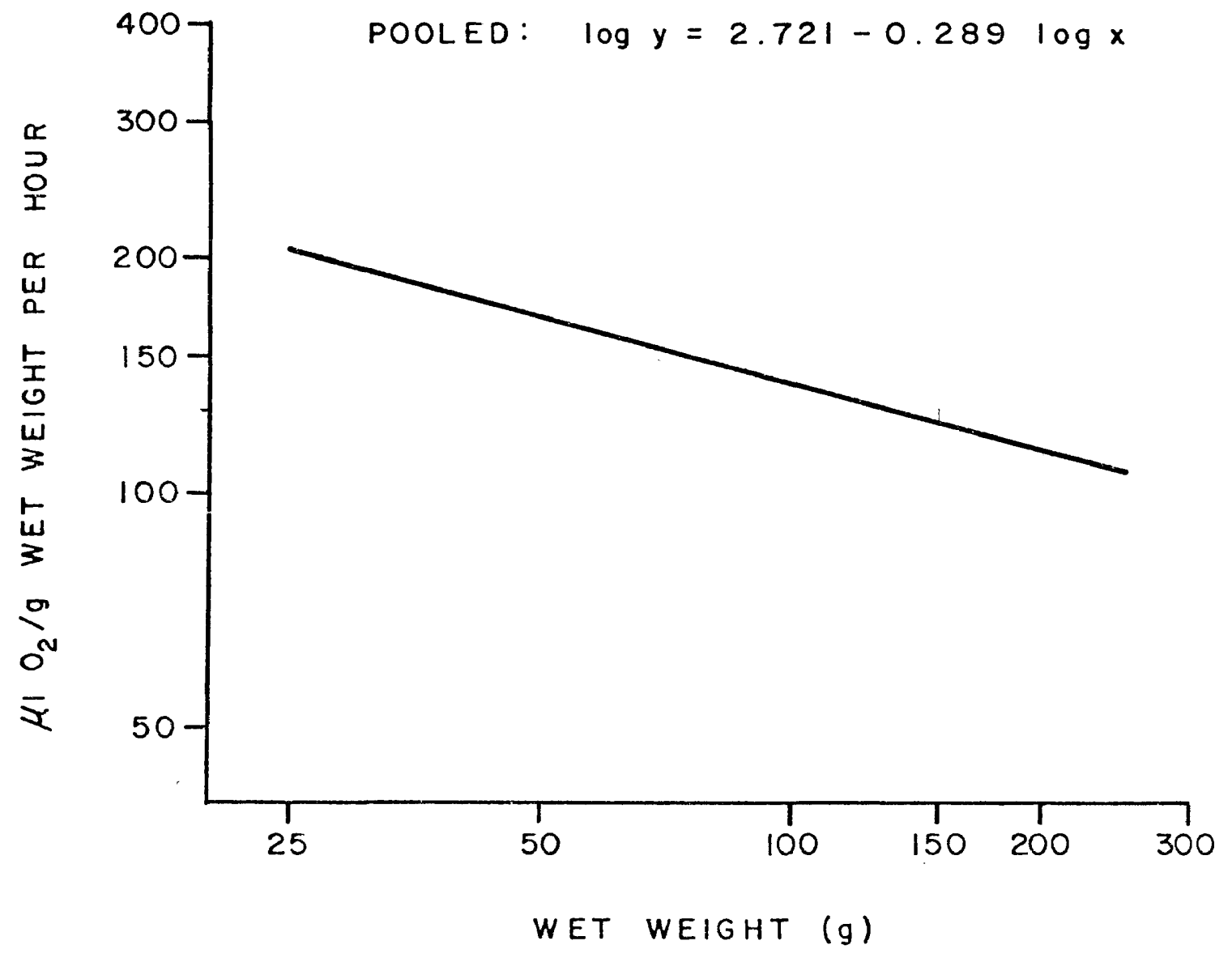


FIGURE 7. Four factor linear plot showing the effects of acclimation temperature, acclimation salinity, experimental temperature, and experimental salinity on the oxygen consumption of Callinectes sapidus. 


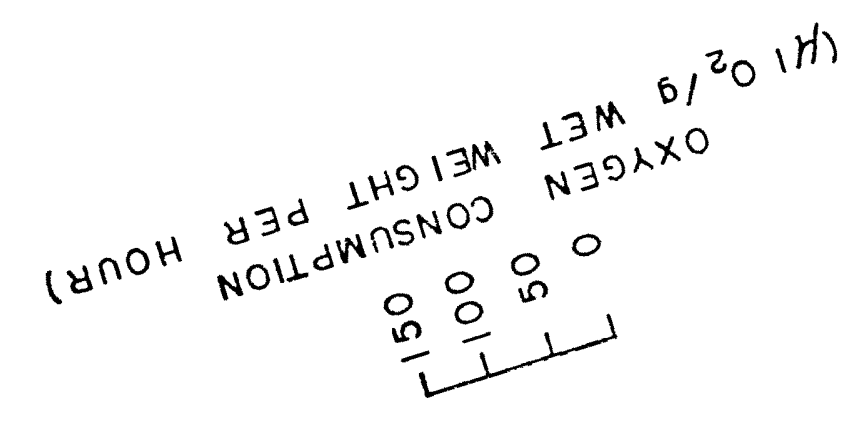

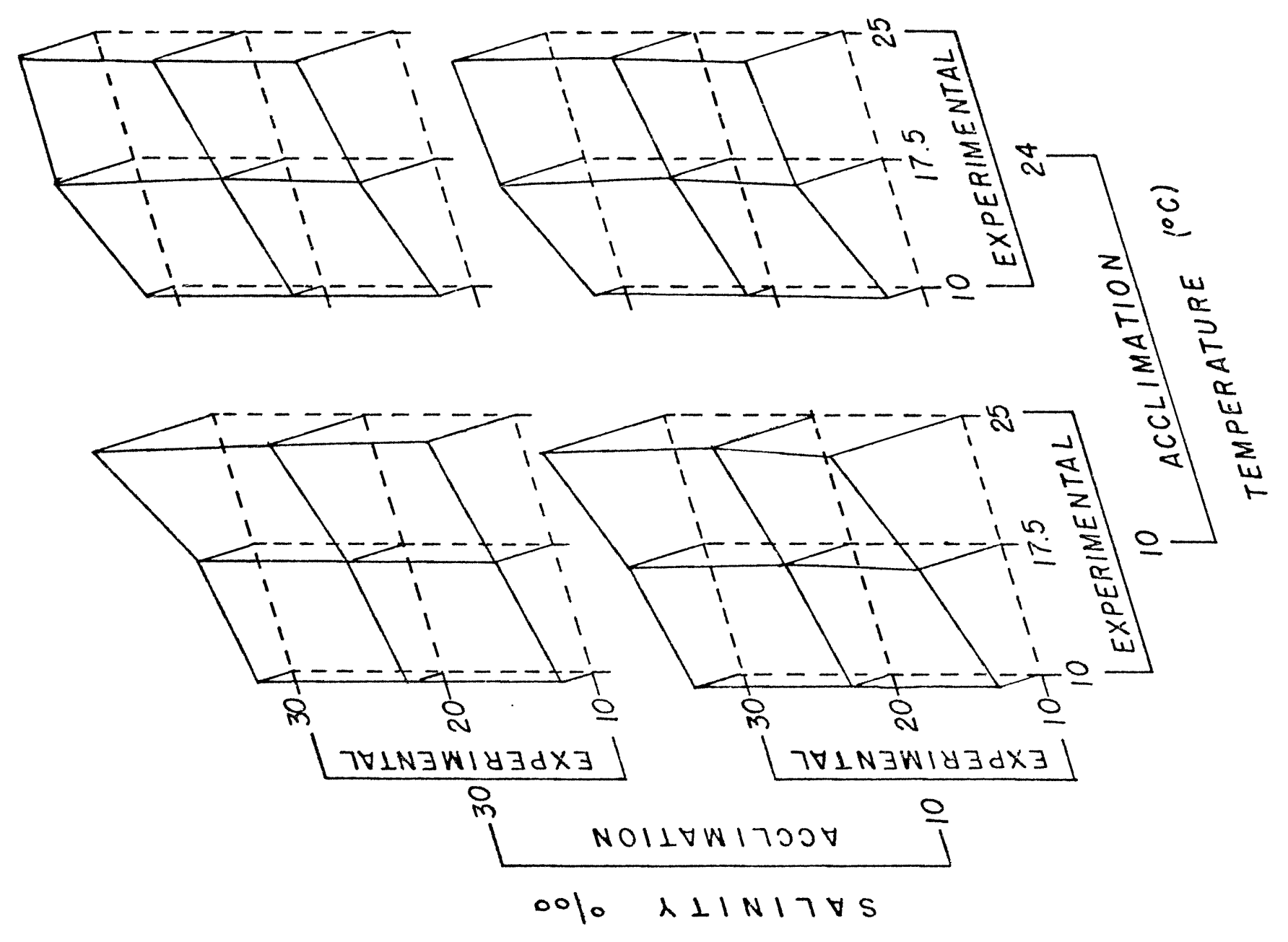


TABLE 1. Four factor analysis of variance for the effects of acclimation temperature, acclimation salinity, experimental temperature, and experimental

salinity on the oxygen consumption of Callinectes sapidus (**, significant at $1 \%$ level; *, significant at 5\% level; ns, not significant)

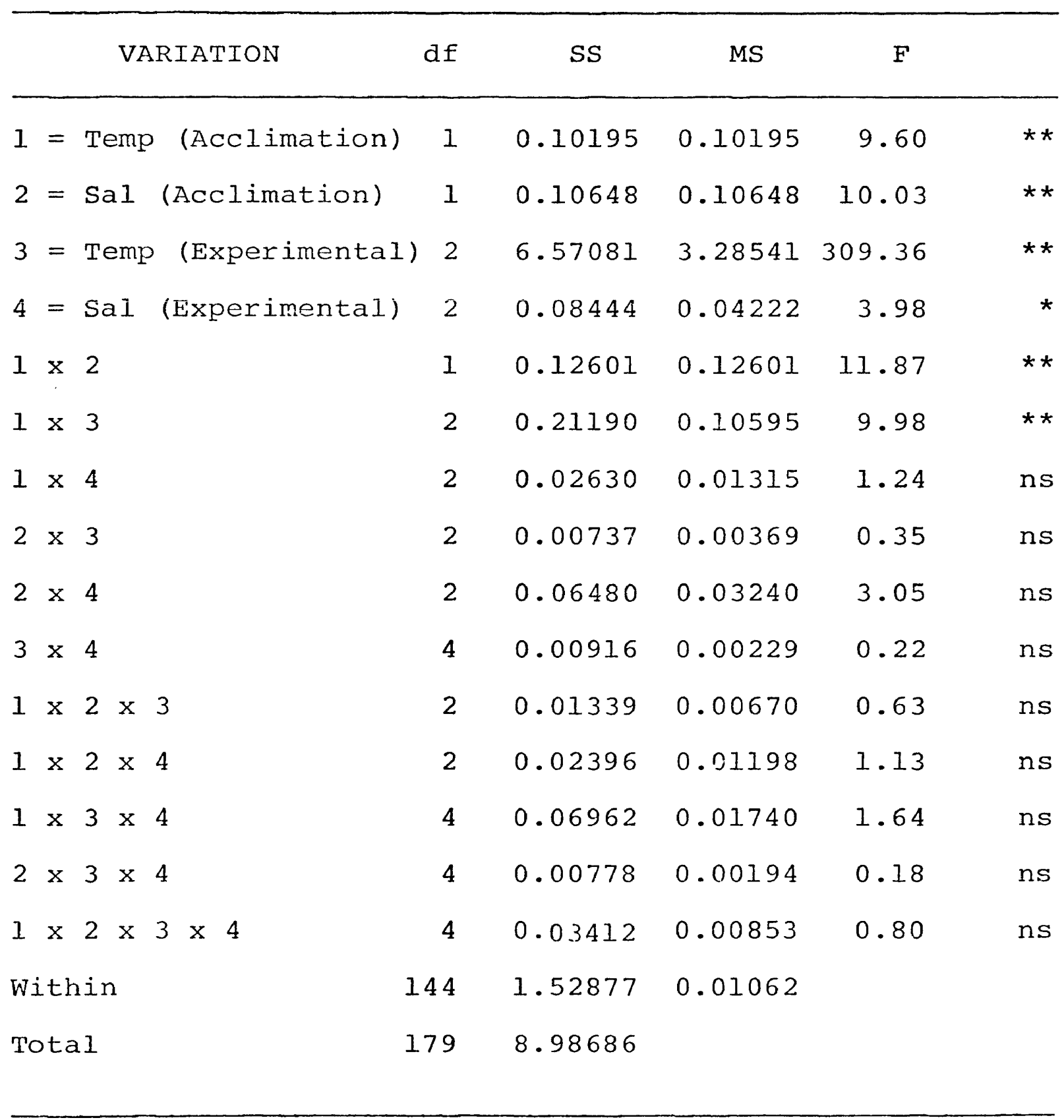


TABLE 2. Student-Newman-Keuls multiple comparison test for the cell means from the temperature-salinity experiment. Vertical bars represent equal means $(\mathrm{P}<0.05)$.

Acclimation

Temp. Sal.

$\left({ }^{\circ} \mathrm{C}\right) \quad(\% / 00)$
Experimental

Temp. Sal.

$\left({ }^{C}\right) \quad(0 / 0) \quad$ Ranked Means

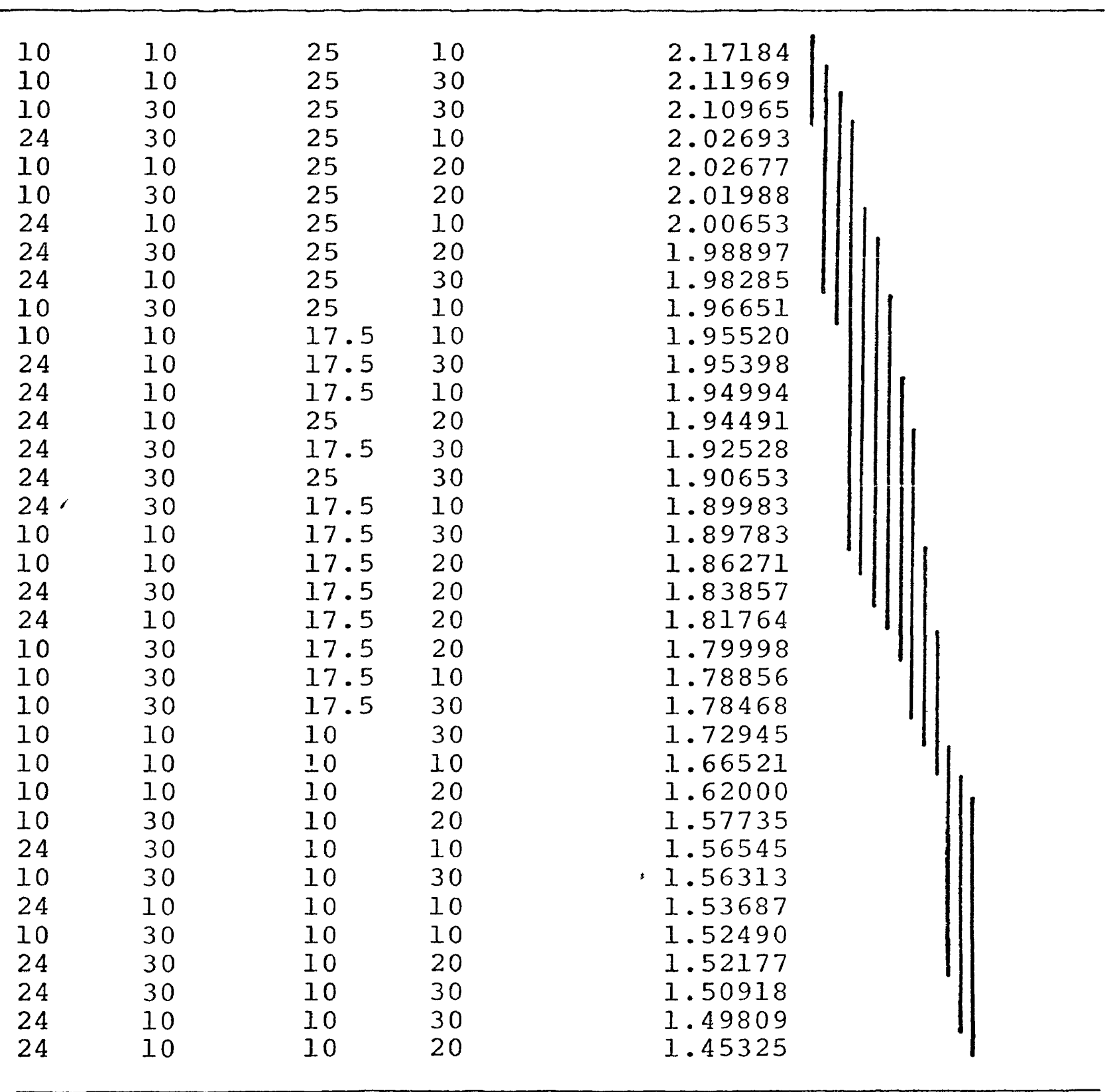


lower than that for $10 \%$ or $30 \%$. Since the $\mathrm{F}$ value for the salinity effect is relatively small (Table 1) and can be considered borderline (critical $\mathrm{F}$ at the 5\% level is 3.92), and since the means are not different, it is probable that little, if any, salinity effect is present. For this reason, and to simplify interpretation of the data, the values for the experimental salinities were pooled, allowing the effects within each acclimation combination to be represented by a single curve (Fig. 8).

The effect of acclimation salinity is most noticeable at the lower acclimation temperature. For a given experimental temperature, the oxygen consumption of $10^{\circ} \mathrm{C}$ crabs is higher for crabs acclimated to 100/00 than for those acclimated to $30 \%$. Interaction between acclimation temperature and salinity becomes apparent at $24^{\circ} \mathrm{C}$ acclimation. For any given test temperature, oxygen consumption does not differ significantly from one acclimation salinity to another.

The most significant effect is that of experimental temperature (Table 1). Generally, the oxygen consumption rate increases with an increase in temperature regardless of the acclimation condition. A multiple range test (Table 3 ) indicated that at the $10^{\circ} \mathrm{C}$ acclimation temperature, regardless of acclimation salinity, oxygen consumption values measured at $17.5^{\circ} \mathrm{C}$ are significantly higher than those measured at $10^{\circ} \mathrm{C}$. Also, oxygen consumption 
FIGURE 8. Semi-log plot showing the effects of acclimation temperature, acclimation salinity, and experimental temperature on the oxygen consumption of Callinectes sapidus. Experimental salinities are pooled. 


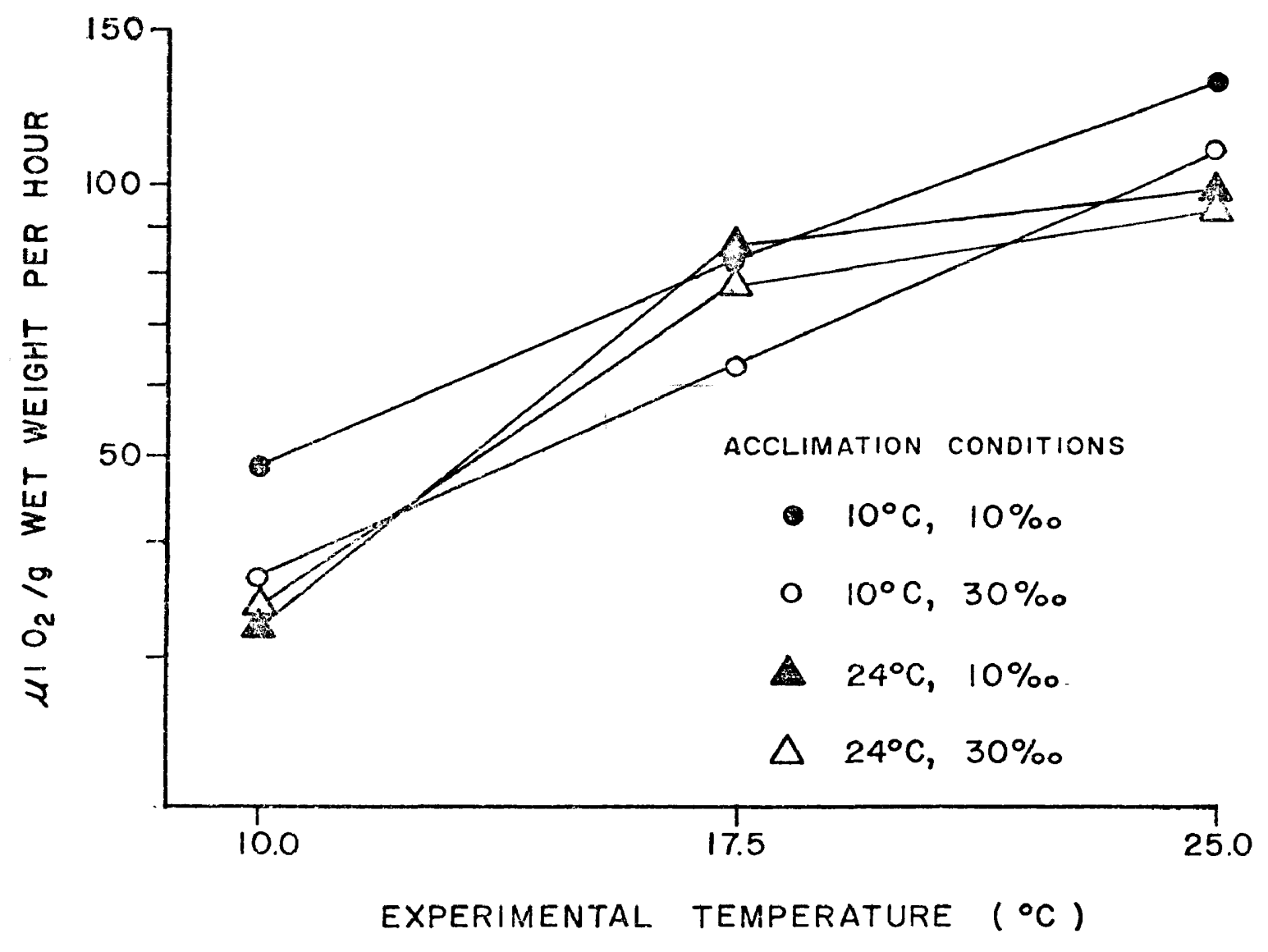


TABLE 3. Student-Newman-Keuls multiple comparison test for the cell means from the temperature-salinity experiment. Experimental salinities are pooled. Vertical bars represent equal means $(\mathrm{P}<0.05)$.

Acclimation Temp. Sal. $\left({ }^{\circ} \mathrm{C}\right) \quad(\mathrm{O} / \mathrm{OO})$
Experimental

Temp.

$\left({ }^{\circ} \mathrm{C}\right)$

Ranked Means

25

25

25

25

17.5

1.90718

17.5

1. 90524

17.5

1.88789

17.5

1.79107

10

1. 67155

10

1. 55512

10

1. 53213

10

1.49607

$\begin{array}{llll}24 & 10 & 10 & 1.49607\end{array}$


values measured at $25^{\circ} \mathrm{C}$ are significantly higher than those measured at $17.5^{\circ} \mathrm{C}$. For the $24^{\circ} \mathrm{C}$ acclimation temperature, regardless of acclimation salinity, values measured at $17.5^{\circ} \mathrm{C}$ are significantly higher than those measured at $10^{\circ} \mathrm{C}$. However, values measured at $25^{\circ} \mathrm{C}$ are not significantly different from those measured at $17.5^{\circ} \mathrm{C}$ for crabs acclimated to $10 \%$ and are only slightly higher for crabs acclimated to $30^{\circ} / 00$.

It is apparent from the above that acclimation temperature affects the reactions of the oxygen consumption

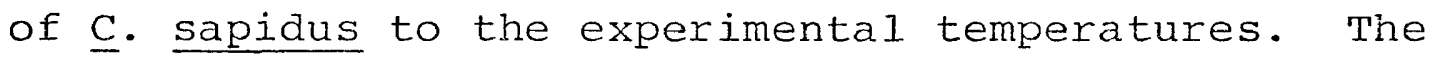
oxygen consumption of crabs acclimated to $24^{\circ} \mathrm{C}$ is Iittle affected by an increase in experimental temperature above $17.5^{\circ} \mathrm{C}$, while that of crabs acclimated to $10^{\circ} \mathrm{C}$ continues to increase with temperature above $17.5^{\circ} \mathrm{C}$.

The oxygen consumption of cold acclimated animals tends to be higher than that of warm acclimated animals when measured at $10^{\circ} \mathrm{C}$ or $25^{\circ} \mathrm{C}$, but not at $17.5^{\circ} \mathrm{C}$. Mean comparisons showed that for animals acclimated to $10^{\circ} \% 0$, oxygen consumption measured at $10^{\circ} \mathrm{C}$ and $25^{\circ} \mathrm{C}$ for cold acclimated animals is higher than that for warm acclimated animals. When measured at $17.5^{\circ} \mathrm{C}$, the oxygen consumption rates are not different. For crabs acclimated to $30^{\circ} / 00$, the oxygen consumption measured at $25^{\circ} \mathrm{C}$ for cold acclimated animals is higher than that for warm acclimated animals. The rates measured at $10^{\circ} \mathrm{C}$ are not different for the two 
acclimation temperatures and the rates measured at $17.5^{\circ} \mathrm{C}$ for cold acclimated animals are lower than those for warm acclimated animals.

Computed $Q_{10}$ values (Table 4 ) for the temperature interval $10-17.5^{\circ} \mathrm{C}$ are higher for crabs acclimated to $24^{\circ} \mathrm{C}$ than for those acclimated to $10^{\circ} \mathrm{C}$; the opposite is true for the $17.5-25^{\circ} \mathrm{C}$ temperature interval. This indicates that warm acclimated crabs are more responsive to temperature in the lower temperature regime while cold acclimated crabs are more responsive to temperature within the warmer regime. This phenomenon, however, seems to be a response of the warm acclimated animals because the $Q_{10}$ 's for the cold acclimated animals remain relatively constant over the $10-24^{\circ} \mathrm{C}$ temperature range.

Recordings of oxygen consumption for both experiments reflected a tendency for blue crabs to regulate oxygen consumption independent of the decreasing dissolved oxygen in the chamber. That is, with some variation, the recordings of oxygen level versus time were straight lines. It was found that at depressed levels of dissolved oxygen, the oxygen consumption of $\underline{C}$. sapidus begins to conform more to the oxygen level in the chamber. The change from regulation to conformity was observed as a break from linearity to curvilinearity in the recording. The mean break point for 14 males was $2.6 \mathrm{mg} / \mathrm{l}$ ( $1.5 \mathrm{mg} / 1-4.4 \mathrm{mg} / \mathrm{l}$ ), while that for 12 females was $2.4 \mathrm{mg} / 1$ (1.3 mg/1-3.6 mg/1) 
TABIE 4. Temperature coefficients $\left(Q_{10}\right.$ 's) for the oxygen consumption-experimental temperature curves from the temperature-salinity experiment. Experimental salinities are pooled. (See Fig. 8)

\begin{tabular}{lcc}
\hline $\begin{array}{c}\text { Acclimatior } \\
\text { Condition }\end{array}$ & $\begin{array}{c}\text { Temperature } \begin{array}{c}\text { Intervals } \\
10-17.5^{\circ} \mathrm{C}\end{array} \\
17.55^{\circ} \mathrm{C}\end{array}$ \\
\hline & \multicolumn{2}{c}{$\mathrm{Q}_{10}{ }^{\prime} \mathrm{s}$} \\
$10^{\circ} \mathrm{C}, 10^{\circ} / 00$ & 1.99 & 1.87 \\
$10^{\circ} \mathrm{C}, 30^{\circ} / 00$ & 2.07 & 2.09 \\
$24^{\circ} \mathrm{C}, 10^{\circ} / 00$ & 3.62 & 1.24 \\
$24{ }^{\circ} \mathrm{C}, 30^{\circ} / 00$ & 3.02 & 1.31 \\
\hline
\end{tabular}


remaining oxygen. The overall mean break point was $2.5 \mathrm{mg} / 1$. There was no difference between sexes $(P<0.05)$, and regression analysis indicated no significant effect of weight $(\mathrm{F}=0.152, \mathrm{P}>0.10)$. 


\section{DISCUSSION}

\section{Variability}

The high variability noted for the oxygen consumption rates of $\underline{C}$. sapidus is not without precedent. Ayers (1938) determined oxygen consumption for 10 blue crabs of undisclosed size and derived values ranging from 0.83-1.39 $\mu 1 \mathrm{O}_{2} / \mathrm{g}$ per hr. King (1965) found that the variability of metabolic rates determined for juvenile $\underline{C}$. sapidus exceeded that for three other species from the same study. Leffler (1972) observed that the variability of oxygen consumption of juvenile $\underline{c}$ sapidus increased with temperature until the values ranged over $50 \mu 1 \mathrm{O}_{2} / \mathrm{g}$ per hr for four crabs at $34^{\circ} \mathrm{C}$. Ranges of oxygen consumption values as great as $100 \mu 10_{2} / 9$ per hr between crabs and as great as $78 \mu 10_{2} / g$ per hr for the same crab under uniform conditions were reported by Robert (1971).

Recently, variable activity has been suggested as the cause of high variation between weight specific oxygen consumption values found for both Panulirus interruptus and Cancer productus larvae (Belman and Childress, 1973). Robert (1971) attempted to explain the variability of oxygen consumption values for the blue crab by attributing 
it to activity as well as to weight and nutrition. Thus, it is possible that the variability of the present sexweight data is due to variable activity of the crabs, since they were unrestrained during the determinations. Although the crabs were allowed a 30-minute adjustment period prior to each run, it is unreasonable to expect each one of a large number of crabs to remain nonmotile for any length of time without imposed restraint. The high variability of oxygen consumption rates, however, was also encountered in the immobilized crabs from the temperature-salinity experiment. This discrepancy may be explained by the observation that the latter crabs tended to exert tension against their restraints, and, therefore, could have increased their metabolic rates by isometric contractions. The major consequence in the present study would be that the metabolic rates determined are not all standard rates.

While variations in activity could account for part of the variability of the data, it is probable that other factors were also involved. The variability due to weight, indicated by the regression derived from the sex-weight data, accounted for nearly $25 \%$ of the total variability. The values from the temperature-salinity experiment were not corrected for weight, because the variability due to weight over the weight range used appeared insignificant compared to the total variability of the data (Fig. 4). 
Natural variation could be another source of the observed variability. Cargo (personal communication) was impressed with the variability of the morphological features of the blue crab and thought this variability might be the result of salinity differences. Lynch and DuPaul (personal communication) have tentatively attributed the high variability associated with the blue crab to the fluctuating estuarine environment.

Other sources of variability could be effects of diurnal or tidal cycles, lack of precise temperature controls in the sex-weight experiment, shell hardness, salinity changes, and inadequate adjustment to experimental conditions in both experiments, as well as the use of wet weights. During weighing, water can become trapped in the branchial chamber and, in some cases, actually held there intentionally by the crab. Variations in the amount of water retained among crabs could have affected the wet weight values, though much effort was expended to rid the crabs of this water.

Nutritional state has been shown to have an effect on the metabolism of various crabs (Roberts, 1957; Vernberg, 1959; Marsden, et al., 1973). Robert (1971) attributed some of the variability of her data to differences in the willingness of the blue crabs to accept food. However, Vernberg (1959) and Marsden, et al. (1973) indicated for Uca and Carcinus, respectively, that it takes at least a 
week for differences in metabolism between starved and fed crabs to become significant. The crabs used in the present study all had access to food within 18 hours of the oxygen consumption rate determinations, and it seems improbable that small variations in nutritional state resulting from varying food acceptance contributed significantly to the variability of the data.

Weight

The effect of weight on the metabolism of poikilotherms has been given considerable attention (Prosser and Brown, 1961). Generally, it has been found that as weight increases, the weight-specific metabolic rate decreases. This relationship applies to both inter- and intra-specific comparisons and is usually best expressed as a double logarithmic function where

$$
\log \frac{M}{W}=b^{\prime} \log W+\log K,
$$

where $\frac{M}{W}$ is the weight specific metabolism, $W$ is the weight of the animal, $M$ is the total metabolism per unit time, $b^{\prime}$ is the slope of the regression line $\left(b^{\prime}=b-1\right.$ where $\mathrm{b}$ is the slope of the relationship between total metabolism and weight), and $\mathrm{K}$ is the $\mathrm{Y}$-intercept.

For purposes of comparison, the value of $b^{\prime}$ is of primary importance. The average $b^{\prime}$ for crustaceans seems to be somewhere between -0.20 (Zeuthen, 1953) and -0.15 (Scholander, et al., 1953), although the variation about 
these values is quite extensive, even intra-specifically. Therefore, the $b^{\prime}$ value of -0.29 found for $\underline{c}$. sapidus, while more negative than the average, falls within the wide range of values found for crustacea (Vernberg, 1959; Gilchrist, 1956; Rao and Ganopati, 1969; Madanmohanrao and Rao, 1962; Barnes and Barnes, 1969; Rao, 1958). It also corresponds well with values exhibited by other Brachyura (Teal, 1959; Vernberg, 1959; Roberts, 1957; Madanmohanrao and Rao, 1962; Leffler, 1972; Weymouth, et al., 1944).

According to Prosser and Brown (1961), interpretations of size correlations of metabolism are difficult. The fact that $b^{\prime}$ values for crustacea generally fall between -0.33 and zero makes interpretation more difficult, because it is not known if these values are dependent on the weight of the metabolically active tissue, the surface area, or both (Leffler, 1973). Meaningful interpretations of the b' values would be possible by more research on the determination of the mechanisms responsible for the effects of such variables as temperature and salinity on the weight-metabolism relationship.

$\underline{\text { Sex }}$

In the few cases studied, the effect of sex on metabolic rates in crustacea has been shown to be negligible, except in cases of extreme morphological differences between sexes. Edwards and Irving (1943a) found 
that male Emerita talpoida have higher oxygen consumption rates than females, but attributed the difference to the smaller size of the male. Talorchestia megalopthalma exhibits no sexual differences in metabolic rate (Edwards and Irving, 1943b). Gilchrist (1956) claimed that the rate of oxygen consumption of male Artemia salina is different from that of females in relation to salinity, but morphological changes caused by changes in salinity may be involved. Vernberg (1956) determined the oxygen consumption rates of gill tissue and midgut gland of Callinectes sapidus and found no differences between sexes for either tissue. It is consistent therefore that no sexual differences were found for whole animal oxygen consumption rates in $\underline{C}$. sapidus. Apparently, any differences in sexual morphology and development in the blue crab are not significant enough to affect its metabolic rate.

\section{$\underline{\text { Salinity }}$}

The failure of the metabolism of $\underline{C}$. sapidus to reflect experimental salinity effects is atypical when compared to results from studies on some crustacea (Poat, et al., 1971; Lance, 1965; Madanmohanrao and Rao, 1962; Flemister and Flemister, 1951; Kutty, et al., 1971; Rao, 1958), but such a lack of an effect is not unique, even among decapods (Madanmohanrao and Rao, 1962). This lack of a salinity effect seems to contradict results of King 
(1965), who observed that oxygen consumption of whole c. sapidus increases with a decrease in salinity. However, she used immature crabs, and it has been shown that adult and immature blue crabs can differ in their reactions to changing salinities (Tagatz, 1971). Also, metabolic differences between large and small animals in response to varying salinities exist for other crustacea (Madanmohanrao and Rao, 1962).

The effect of salinity acclimation on the oxygen consumption of $\underline{\underline{C}}$. sapidus is similar to that observed by Dehnel (1960) for Hemigrapsus nudus in that there is an interaction with acclimation temperature. $\underline{\text { H. nudus }}$ was tested at only one temperature $\left(10^{\circ} \mathrm{C}\right)$, and it was found that cold acclimated crabs respire more at low acclimation salinities while warm acclimated crabs respire more at high acclimation salinities. Figure 8 shows that at $10^{\circ} \mathrm{C}$ this tendency is present for $\underline{C}$. sapidus, but no acclimation salinity effect at high acclimation temperatures is evident. The similarity in the two species is further upset by the fact that $\underline{\mathrm{H}}$. nudus shows no acclimation salinity effect at higher experimental temperatures.

Other interactions similar to those described for C. sapidus and $\underline{H}$. nudus are not known to exist. However, both the lack of a response to acclimation salinity and the lowered metabolic rate with increased acclimation salinity demonstrated by the blue crab have been shown 
separately for other crustacea (Kinne, 1967). Significantly, the literature indicates that some temperature dependence of the responses of these crustacea to acclimation salinities similar to that demonstrated by $\underline{C}$. sapidus may be present. Generally, no response to acclimation salinity seems to be associated with high acclimation temperatures (Gilchrist, 1956; MCFarland and Pickens, 1965; Kutty, et al., 1971) but a response does seem to be associated with low acclimation temperatures (Dehnel, 1960).

Aside from geographical and habitat considerations, Dehnel (1960) offered no physiological explanation for the acclimation temperature, acclimation salinity interaction observed for $\underline{H}$. nudus. In the present study, it is tempting to attribute the interaction observed for $\underline{c}$. sapidus to accumulated temperature and salinity stresses as well as to differing time courses and/or degrees of acclimation to the salinities as a function of the acclimation temperatures. However, it is difficult to reconcile the lack of acute salinity effects to these hypotheses.

It has been suggested that the effects of salinity on metabolism can be explained by differences in required osmotic work at different salinities (Flemister and Flemister, 1951; Dehnel, 1960; Lance, 1965). This theory has been refuted by potts and Parry (1964) who argued that the metabolic demands of ion transport cannot explain the 
magnitude of the enhanced metabolic rates found in animals transferred to dilute sea water. Rather, most of the increase in metabolic rate takes place in tissues not performing osmotic work. Evidence to this effect has also been offered by Lofts (1964), King (1965), Kutty, et al. (1971), Poat, et al. (1971), and more recently, by siebers, et al. (1972).

Callinectes sapidus has been shown to be a hyperosmotic regulator in up to about $80 \%$ sea water (Tagatz, 1971). Therefore, the lack of an acclimation salinity effect on the metabolism of the crab acclimated to high temperatures as well as the lack of an acute salinity effect illustrates that the amount of work involved in osmoregulation is probably not sufficient to account for increased metabolic rates. At least on the basis of required osmotic work, the responses or lack of responses to acute and acclimation salinity changes observed for the blue crab are not anomalous.

Alternatively, the presence of activity differences in abnormal salinities has been offered as an explanation for the effects of salinity on metabolic rates (Gross, 1957; Vernberg and Vernberg, 1972). Dehnel (1960), however, has cited evidence which shows that the metabolic rates of even sessile animals can be affected by salinity changes. Furthermore, he indicated that while the oxygen 
consumption of Mytilus is higher at low salinities, the mechanical activity of its gill cilia and the frequency of its heartbeat are lower. Therefore, attempts to explain salinity effects on metabolism on the basis of activity changes are questionable.

The observed effects of salinity on metabolism of the blue crab appear to support the latter contention. If activity j.s responsible for salinity effects, then the crabs in the present study should have shown no salinity effects, since they were immobilized. However, acclimation to salinity did affect the metabolism of the crabs. The involvement of isometric tension against the restraints is unlikely because experimental salinity had no effect. In addition, no differences in activity between $10^{\circ} \% 00$ and $30^{\circ} / 00$ acclimated crabs were noticed in the holding tanks at the same temperature. This was especially noticeable for the crabs held at $10^{\circ} \mathrm{C}$, where no activity was observed. It is at this low acclimation temperature that the effect of acclimation salinity on the metabolism of the crab occurs.

Another explanation for the effects of salinity on metabolism involves changes in cellular hydration. Schlieper (Remane and Schlieper, 1958; c.f. Potts and Parry, 1964) has suggested that the effects of salinity on the metabolic rates of brackish water animals might be 
the result of changes in the hydration of the tissues and subsequent effects on enzyme activity. King (1965), however, has discounted cellular hydration changes as the cause for metabolic changes in excised gills of $\underline{C}$. sapidus because she found hydration changes to be consistent while metabolic rates are highly variable between crabs.

Thus, while many hypotheses have been offered to explain the effects of salinity on the metabolism of crustacea, no single one has really been satisfactory. It also appears as if none of the more popular explanations is compatible with the results obtained from the present study. It must therefore be assumed that either another factor, different from those already investigated, is responsible, or, more probably, that more than one factor is involved (Kinne, 1971).

\section{Temperature}

In general, the metabolic rates of crustaceans increase with temperature when measured over a range of experimental temperatures (Prosser and Brown, 1961; Wolvekamp and Waterman, 1960; Kinne, 1970; Vernberg and

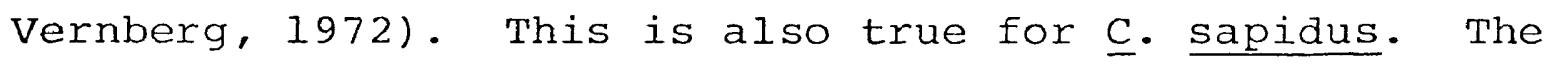
only exception is that within the higher temperature interval, the metabolic rates of the warm acclimated crabs are largely unaffected. Such temperature insensitive metabolism has been found for other Brachyura (Vernberg, 
1959; Vernberg and Vernberg, 1972) as well as for barnacles (Barnes and Barnes, 1969). The occurrence of this relatively temperature insensitive metabolism for warmacclimated blue crabs lends support to Vernberg and Vernberg's (1969) observation that the thermal range of metabolic insensitivity to temperature usually coincides with the temperature regime of an animal's habitat. On this basis, the cold acclimated blue crabs should have shown metabolic temperature insensitivity within the lower temperature interval. This did not occur and reflects a pattern reported by Barnes and Barnes (1969) for Balanus.

Since they were captured from water with a temperature close to that used in the laboratory, the warm acclimated crabs were probably unaffected by further temperature acclimation. It is possible, however, that longer acclimation to the cold temperatures is necessary to approximate what Vernberg and Vernberg (1969) consider to be habitat temperature. While Robert's (1971) time criterion for acclimation to temperature, which was based on oxygen consumption studies, was used in this study, Tagatz (1969) has suggested on the basis of thermal tolerance studies that temperature acclimation in the blue crab takes considerably longer.

In support of Tagatz (1969) are the effects of acclimation temperature on the metabolism of the blue crab. 
While the effects of acclimation salinity make interpretation of the acclimation temperature effects difficult, it is notable at $10^{\circ} \mathrm{C}$ and $17.5^{\circ} \mathrm{C}$ that some of the metabolic rates for the cold acclimated animals are not higher than those for the warm acclimated animals. However, at $25^{\circ} \mathrm{C}$ the rates for cold acclimated animals are higher regardless of salinity. This indicates that acclimation to cold was incomplete in the classical sense, where cold acclimated animals characteristically show higher metabolic rates than warm acclimated animals at any experimental temperature (Prosser and Brown, 1961). It is evident, however, that some temperature acclimation has occurred with reference to the lower experimental temperatures because some rotation of the curve has occurred, though in a direction opposite that at the higher experimental temperatures.

It is possible that $\underline{C}$. sapidus never completely metabolically acclimates to cold temperatures. This has been indicated previously on the basis of cytochrome C oxidase activity by Vernberg and Vernberg (1968). Robert (1971) found that the blue crab does not show the classic higher rate function of cold acclimated animals over warm acclimated animals at intermediate temperatures. This finding closely parallels the results from the present study. It is possible that these two authors did not allow enough time for complete acclimation to temperature. However, cold acclimated animals in the laboratory as well 
as animals collected from the field in winter exhibited cold torpor, and Bullock (1955) has observed that where seasonal (temperature) acclimation is absent, an animal is usually immobilized by cold.

Thus, it is possible that the cold acclimated animals do not show any temperature independent metabolism at low experimental temperatures because they were not completely acclimated to cold. It is notable, however, that while this temperature independent metabolism is absent, the cold acclimated crabs have lower $Q_{10}$ 's at the higher experimental temperatures and higher $Q_{10}$ 's at the higher experimental temperatures than the warm acclimated crabs.

Another explanation is that the experimental temperature intervals are too large to show the range of temperature independent metabolism for the cold acclimated crabs (Vernberg, 1959). This range could conceivably be smaller than that for warm acclimated animals or in a different position relative to the experimental temperatures than that for the warm acclimated animals.

Another possibility which must be considered is that cold acclimated crabs simply do not show a range of temperature independent metabolism over any range of temperature, regardless of the degree of acclimation. Certainly, much of the literature dealing with the effects of temperature on the metabolism of other crustacea demonstrates no such effect (e.g. Hagerman, 1970; Kutty, et al., 1971; 
Barnes and Barnes, 1969; Scholander, et al., 1953; Vernberg and Vernberg, 1972). However, again, it is possible that these and other studies would show a range of temperature independent metabolism if the experimental temperature intervals were shortened.

Newell and Northcroft (1967) and Halcrow and Boyd (1967) have suggested that increases in metabolic rate associated with increases in temperature are the result of changing levels of activity and that "resting" metabolism is largely temperature independent. Tribe and Bowler (1968) have convincingly challenged this hypothesis on the basis of literature, experimental techniques, and the fact that temperature independent "resting" metabolism may really reflect anaerobic metabolism. Activity was probably not responsible for the metabolic responses to temperature observed for the blue crab, because the crabs were immobilized. This contention is supported by Newell (1966) who noted that permanently immersed poikilotherms do not seem to show temperature independent "resting" metabolism. For this reason, it would also be difficult to attribute the temperature effects to isometric activity in the immobilized crabs.

\section{Oxygen}

Amberson, et al. (1924) indicated that Callinectes sapidus is an oxyconformer. However, the recordings from 
the present study show that the blue crab is more an oxyregulator until a critical low level of oxygen is reached, at which point it becomes an oxyconformer. This critical level compares very well with critical levels found for two species of lobster (Winget, 1969; Nimura and Inoue, 1969). Although it was not observed, it is suspected that the regulation of oxygen uptake is carried out by an increase in ventilation rates as the oxygen tension of the water decreases. In this case, the critical oxygen level is probably the level at which maximum ventilation cannot compensate for the lack of oxygen tension. It is also possible that some circulatory modification to facilitate withdrawal of oxygen from the water also occurs as ambient oxygen levels decrease.

While the blue crab appears to change from an oxyregulator to an oxyconformer at low levels of dissolved oxygen, it should be understood that this change, though easily detected, is relative. At higher dissolved oxygen levels, the blue crabs are fairly efficient, but imperfect, oxygen regulators. Indeed, Mangum (1970) asserts that oxygen regulation is often imperfect and that oxygen consumption is influenced to some extent over the entire $\mathrm{pO}_{2}$ range. 


\section{SUMMARY}

1. The rate of oxygen consumption of the blue crab exhibits a high degree of variability.

2. The weight-specific oxygen consumption of the blue crab decreases as wet weight increases.

3. Under the conditions of the study, no differences in oxygen consumption were found between male and female blue crabs.

4. The crabs are little affected by acclimation to salinity at higher acclimation temperatures. Crabs acclimated to $10 \%$ have higher oxygen consumption rates than $30 \%$ crabs when acclimated to lower temperatures. Experimental salinity has little or no effect on the oxygen consumption of the crab.

5. The oxygen consumption of the crabs generally increases with increasing experimental temperature. Warm acclimated crabs, however, show a relatively temperature independent metabolism at higher experimental temperatures. Acclimation to cold temperatures seems to be incomplete, because the oxygen consumption of the cold acclimated crabs is not higher than that of the warm acclimated crabs at all experimental temperatures. 
6. The crabs regulate their oxygen uptake relatively independent of the dissolved oxygen supply down to an average critical level of $2.5 \mathrm{mg} / 1$, which is unaffected by sex or weight. 
APPENDICES 


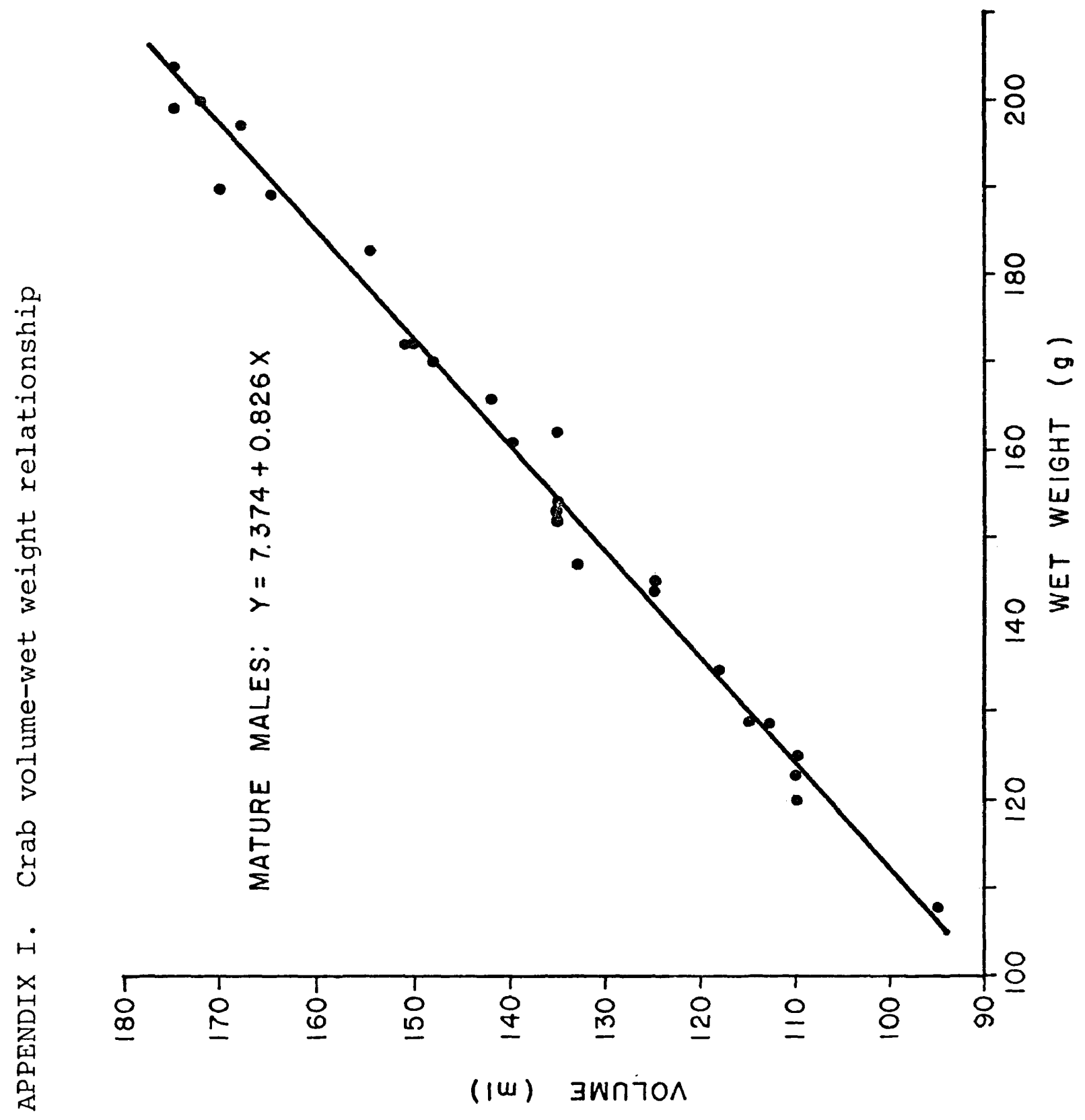


Ar h,

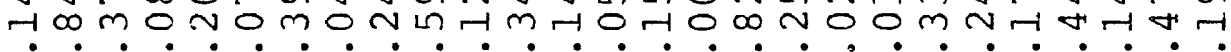

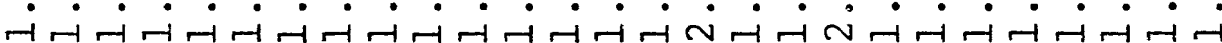

Lก 6 a HNLा IN

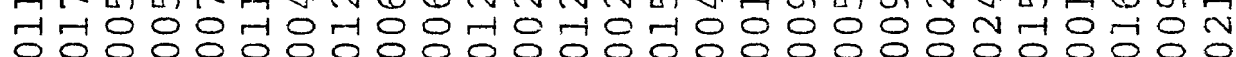
000000000000000000000000000

$\mathrm{NH}$ H $N$ H $N$ H

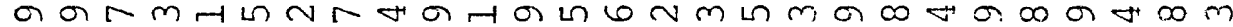
HHN $\dot{\sim} \dot{\sim} \dot{\sim} \dot{\sim} \dot{\sim} \dot{\sim} \dot{\sim} \dot{\sim} \dot{\sim} \dot{\sim} \dot{\sim} \dot{\sim} \dot{\sim} \dot{\sim} \dot{\sim} \dot{\sim} \dot{\sim} \dot{\sim}$

Hm-10

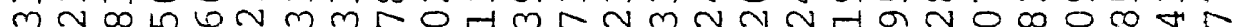
Hmo00 000000000000000000000000000

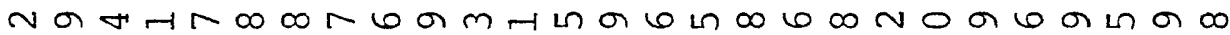

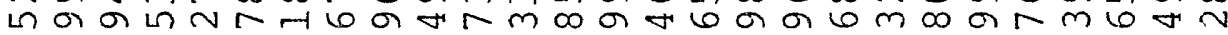



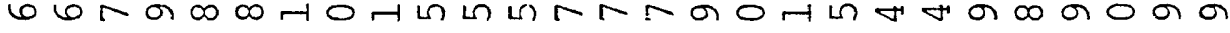

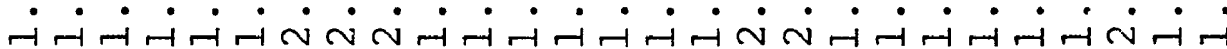

000000000000000000000000000

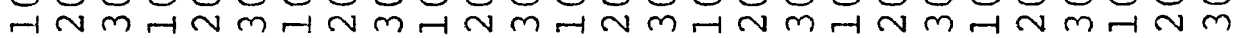

का


\& $\sim 2$

崖

.-.

(1) $\dot{0}$

至

$x \in$

$\stackrel{0}{\stackrel{0}{2}}$

正

(1) तु$$
\text { 至 }
$$

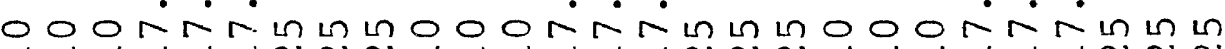
HनHम

000000000000000000000000000

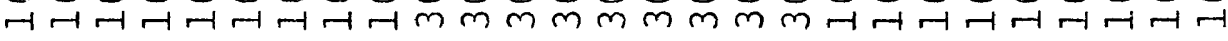

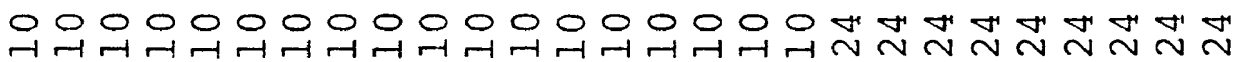


006 L

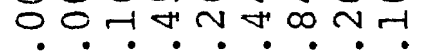

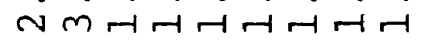

¿̇
0
0

$H$

-

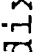

Ð

वे

बi
,

$\pm$

है

(9)

3

궁

○

$\Sigma$

牙

of

(ब) ते

3

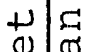

3

$\sum$

N $0 \mathrm{~m}$ ! $\infty \mathrm{N}$ L ना 000000000

ก $4 M N N$ H \% 66 \% 6 N N О $00 \% \mathrm{~m}$ ॠ $\dot{\sim} \dot{\sim} \dot{\sim} \dot{\sim} \dot{\sim}$

b $\infty \mathrm{N}$ \% $\mathrm{m}$ o $\infty \mathrm{N}$ $00 \mathrm{moN}+\mathrm{H} \omega \mathrm{m}$

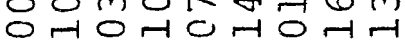
000000000

सr $\omega N 0 \curvearrowleft m N N \infty 0$ เก $\ln \infty \infty$ ด 0 \% $\dot{-i} \dot{-} \dot{-\dot{H}} \dot{\sim} \dot{-i}$

000000000 HM $N$ m $\mathrm{N}$ m

๘ึ घ

Q

E

मे

बि

Q 0

- $\cdot$.

OOONRN I I I

HनHAH $\sim N$

द.

감

$+\infty 0$

艺

ठิ

U

出
0
$m$

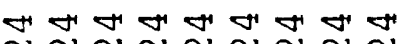
$\pi N \pi N \pi N$ L $\infty \infty$ L $m \sim N \sim$

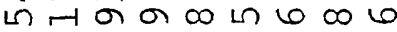

6 in $\infty$ \%

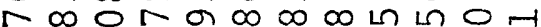

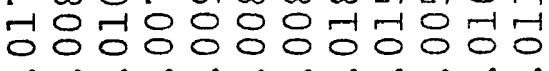

6NHHHOHNH 대내대

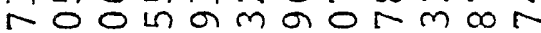

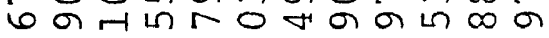

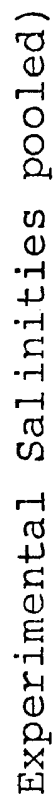

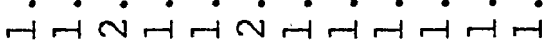

in n in in

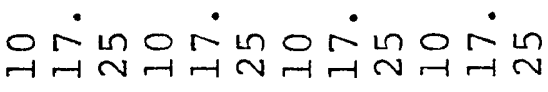

00000000000000

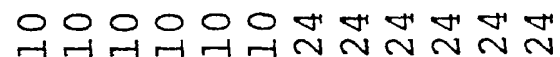




\section{LITERATURE CITED}

Amberson, W. R., H. S. Mayerson, and W. J. Scott. 1924. The influence of oxygen tension upon metabolic rate in invertebrates. J. Gen. Physiol. 7:171-176.

American Public Health Association. 1971. Standard methods for the examination of water and wastewater, including bottom sediment and sludges, 13th edition. American Public Health Association, Inc., New York.

Ayers, J. D. 1938. Relationship of habitat to oxygen consumption by certain estuarine crabs. Ecology 19(4): 523-527.

Barnes, H., and M. Barnes. 1969. Seasonal changes in the acutely determined oxygen consumption and effect of temperature for three common cirripedes, Balanus balanoides (I.), B. balanus (I.), and Chthamalus stellatus (Poli). J. Exp. Mar. Biol. Ecol. 4: 36-50.

Belman, B. W. and J. J. Childress. 1973. Oxygen consumption of the larvae of the lobster Panulirus interruptus (Randall) and the crab Cancer productus Randall. Comp. Biochem. Physiol. 44(A): $821-828$.

Bullock, T. H. 1955. Compensation for temperature in the metabolism and activity of poikilotherms. Biol. Rev. $30: 311-342$.

Dehnel, Paul A. 1960. Effect of temperature and salinity on the oxygen consumption of two intertidal crabs. Biol. Bul1. 118: 215-249.

Dixon, W. J. 1968. BMD Biomedical Computer Programs. U. of California Publications in Automatic Computation, No. 2: 495-510.

Edwards, G. A. and L. Irving. 1943a. The influence of temperature and season upon the oxygen consumption of the sand crab, Emerita talpoida Say. J. Cell. Comp. Physiol. 2l (2): 169-182. 
Edwards, G. A. and I. Irving. 1943b. The influence of season and temperature upon the oxygen consumption of the beach flea, Talorchestia megalopthalma. J. Cell. Comp. Physiol. 21(2): 183-189.

Flemister, L. J. and S. C. Flemister. 1951. Chloride ion regulation and oxygen consumption in the crab Ocypode albicans (Bosq.). Biol. Bull. 101: 259-273.

Gilchrist, R. M. 1956. The oxygen consumption of Artemia salina in different salinities. Hydrobiologia 8: 54-65.

Green, E. J. and D. E. Carritt. 1967. New tables for oxygen saturation of sea water. J. Mar. Res. 25: 140-147.

Gross, W. J. 1957. An analysis of response to osmotic stress in selected decapod crustacea. Biol. Bull. $112(1): 43-63$.

Haefner, P. A., Ir. 1971. The use of elastrator rings for binding crab claws. Ches. Sci. 12(3): 183-184.

Hagerman, I. 1970. The oxygen consumption of Crangon vulgaris (Fabricius) (Crustacea, Natantia) in relation to salinity. Ophelia $7(2)$ : 283-292.

Halcrow, K. and C. M. Boyd. 1967. The oxygen consumption and swimming activity of the amphipod Gammarus oceanicus at different temperatures. Comp. Biochem. Physiol. 23 : $233-242$.

King, E. N. 1965. The oxygen consumption of intact crabs and excised gills as a function of decreased salinity. Comp. Biochem. Physiol. 15: 93-102.

Kinne, O. 1967. Physiology of estuarine organisms with special reference to salinity and temperature. in Estuaries. G. H. Lauff, ed., pp. 525-540. AAAS Publ. No. 83, Washington, D. C.

Kinne, O. 1970. Temperature. Animals. Invertebrates. in Marine Ecology, Vol. I, pt. l. O. Kinne, ed., pp. 407-514. Wiley-Interscience, New York.

Kinne, O. 1971. Salinity. Animals. Invertebrates. in Marine Ecology, Vol. 1, pt. 2. O. Kinne, ed., p $\bar{p}$. 821-995. Wiley-Interscience, New York. 
Kutty, M. N., G. Murugapoopathy, and I. S. Krishnan. 1971 . Influence of salinity and temperature on the oxygen consumption in young juveniles of the Indian prawn Penaeus indicus. Mar. Biol. 11(2): 125-131.

Lance, J. 1965. Respiration and osmotic behavior of the copepod Acartia tonsa in diluted sea water. Comp. Biochem. Physiol. 14: 155-165.

Leffler, C. W. 1972. Some effects of temperature on the growth and metabolic rate of juvenile blue crab, Callinectes sapiaus, in the laboratory. Mar. Biol. 14(2): 104-1 10 .

Leffler, C. W. 1973. Metabolic rate in relation to body size and environmental oxygen concentration in two species of xanthid crabs. Comp. Biochem. Physiol. $44($ A ) : $1047-1052$.

Lofts, B. 1956. The effect of salinity changes on the respiratory rate of the prawn palaemonetes varians (Leach). Jour. Exp. Biol. 33: $730-736$.

Madanmohanrao, G. and K. P. Rao. 1962. Oxygen consumption in a brackish water crustacean sesarma plicatum (Latreille) and a marine crustacean, Lepas anserifera L. Crustaceana 4(1): 75-81.

Mangum, C. P. 1970. Respiratory physiology in annelids. Am. Scient. 58: 641-647.

Mantel, C. H. 1967. Asymmetry potentials, metabolism and sodium fluxes in gills of the blue crab, Callinectes sapidus. Comp. Biochem. Physiol. 20: 743-753.

Marsden, I. E., R. C. Nerell, and M. Ahsanullah. 1973. The effect of starvation on the metabolism of the shore crab, Carcinus maenas. Comp. Biochem. Physiol.

45 (A) : 195-214.

McFarland, W. N. and P. E. Pickens. 1965. The effects of season, temperature and salinity on standard and active oxygen consumption of the grass shrimp palaemonetes pugio Say. Can. J. Zool. 43: 571-585.

Newell, R. C. 1966. Effect of temperature on the metabolism of poikilotherms. Nature 212: 426-428.

Newell, R. C. and H. R. Northcroft. 1967. A re-interpretation of the effect of temperature on the metabolism of certain marine invertebrates. J. Zool., Lond. 151: 277-298. 
Nimura, $Y$. and M. Inoue. 1969. Oxygen uptake rate of the Japanese spiny lobster as related to the environmental oxygen concentration. Bull. Jap. Soc. Scient. Fish. $35: 852-861$.

Poat, P. C., M. I. Thabrew and K. A. Munday. 1971. Cation transport and metabolism as a function of salinity in the excised gill of Carcinus maenas. Comp. Biochem. Physiol. 39 (A) : 699-707.

Potts, W. T. W. and G. Pariy. 1964. Osmotic and Ionic Regulation in Animals, Pergamon Press, New York.

Prosser, C. L. and F. A. Brown. 1961. Comparative Animal Physiology, 2nd Ed., W. B. Saunders Company, Philadelphia.

Rao, C. G. V. P. and P. N. Ganopati. 1969. Oxygen consumption in relation to body size in the barnacle, Balanus tintinnabulum tintinnabulum (L.). Comp. Biochem. Physiol. 28: 193-198.

Rao, P. K. 1958. Oxygen consumption as a function of size and salinity in Metapenaeus monoceros Fab. from marine and brackish water envircnments. J. Exp. Biol. 35: 307-313.

Remane, A. and C. Schlieper. 1958. Die Biologie des Brackwassers, E. Schweizerbartische Verlagsbuchhandlung, stuttgart.

Robert, M. S. 1971. Enzymatic mechanisms during temperature acclimation of the blue crab, Callinectes sapidus. Dissertation, Georgetown U., Thesis 3910.

Roberts, J. I. 1957. Thermal acclimation of metabolism in the crab, Pachygrapsus crassipes Randall. I. The influence of body size, starvation, and molting. Physiol. Zool. 30: 242-255.

Scholander, P. F., W. Flagg, V. Walters, and L. Irving. 1953. Climatic adaptation in arctic and tropical poikilotherms. Physiol. Zool. 26: 67-92.

Siebers, D., C. Lucu, K. R. Sperling, and K. Eberlein. 1972. Kinetics of osmoregulation in the crab Carcinus maenas. Mar. Biol. 17: 291-303. 
Tagatz, M. E. 1969. Some relations of temperature acclimation and salinity to thermal tolerance of the blue crab, Callinectes sapidus. Trans. Amer. Fish. Soc. 98(4): $713-716$.

Tagatz, M. E. 1971. Osmoregulatory ability of blue crabs in different temperature-salinity combinations. Ches. Sci. $12(1): 14-17$.

Tagatz, M. E. and A. B. Hall. 1971. Annotated bibliography on the fishing industry and biology of the blue crab, Callinectes sapidus. NOAA Tech. Rep. NMFS SSRF-640.

Teal, J. M. 1959. Respiration of crabs in Georgia salt marshes and its relation to their ecology. Physiol. Zool. $32(1): 1-14$.

Tribe, M. A. and K. Bowler. 1968. Temperature dependence of "standard metabolic rate" in a poikilotherm. Comp. Biochem. Physiol. 25: 427-436.

Van Engel, W. A. 1962. The blue crab and its fishery in Chesapeake Bay, Part 2: Types of gear for hard crab fishing. Comm. Fish. Rev. 24(9):1-10.

Vernberg, F. J. 1956. Study of the oxygen consumption of excised tissues of certain marine decapod crustacea in relation to habitat. Physiol. Zool. 29: 227-233.

Vernberg, F. J. 1959. Studies on the physiological variation between tropical and temperate zone fiddler crabs of the genus Uca. II. Oxygen consumption of whole organisms. Biol. Bull. 117: 163-184.

Vernberg, F. J. and W. B. Vernberg. 1969. Thermal influence on invertebrate respiration. Ches. Sci. 10: 234-240.

Vernberg, W. B. and F. J. Vernberg. 1968. Physiological diversity in metabolism in marine and terrestrial crustacea. Am. Zool. 8: 449-458.

Vernberg, W. B. and F. J. Vernberg. 1972. Environmental Physiology of Marine Animals, Springer-Verlag, ivew York.

Weymouth, F. W., J. M. Crismon, V. E. Hall, H. S. Belding, and J. Field. 1944. Total and tissue respiration in relation to body weight: a comparison of the kelp crab with other crustaceans and with mammals. Physiol. Zool. 17: 50-71. 
Winget, R. R. 1969. Oxygen consumption and respiration energetics in the spiny lobster, Panulirus interruptus. Biol. Bull. 136: 301-312.

Wolvekamp, H. P. and T. H. Waterman. 1960. Respiration. in The Physiology of Crustacea, Vol. I., T. H. Waterman, $\overline{\mathrm{Ed}} ., \mathrm{pp}$. 35-100. Academic Press, New York.

Zeuthen, E. 1953. Oxygen uptake as related to body size in organisms. Quart. Rev. Biol. 28: 1-12. 


\section{VITA}

\section{Chae Edward Laird}

Born in St. Louis, Missouri, March 12, 1948. Graduated from E. W. Grove High School, Paris, Tennessee, June 1966 ; B.A., Vanderbilt University, Nashville, Teñnessee, 1970 . Entered the College of William and Mary, School of Marine Science, September 1970 and held a National Science Foundation Traineeship from that date to March 1973. 